九州大学学術情報リポジトリ

Kyushu University Institutional Repository

A Systematic Study of the Subgenus Seladonia of the Genus Halictus in Asia (Hymenoptera, Apoidea, Halictidae) III

Dawut, Ahmatjan

Tadauchi, Osamu

https://doi.org/10.5109/2664

出版情報: ESAKIA. 42，pp.121-150，2002-03-31. Entomological Laboratory，Faculty of Agriculture, Kyushu University

バージョン：

権利関係 : 


\title{
A Systematic Study of the Subgenus Seladonia of the Genus Halictus in Asia (Hymenoptera, Apoidea, Halictidae) III *
}

\author{
Ahmatjan DAWUT \\ Entomological Laboratory, Graduate School of Bioresource and Bioenvironmental Science, \\ Kyushu University, Fukuoka, 812-8581 Japan \\ and \\ Osamu TADAUCHI \\ Entomological Laboratory, Faculty of Agriculture, \\ Kyushu University, Fukuoka, 812-8581 Japan
}

\begin{abstract}
Albstract. The third report of a systematic study of the subgenus Seladonia Robertson of the genus Halictus (Hymenoptera, Halictidae) in Asia is presented. Eight species, Halictus (Seladonia) smaragdulus Vachal, H. semitectus Morawitz, H. mongolicus Morawitz, H. lucidipennis Smith, H. varentzovi Morawitz, H. placidulus Blüthgen, $H$. dorni Ebmer, H. tumulorum higashi Sakagami \& Ebmer are treated in the present paper.

Key words: taxonomy, Hymenoptera, Halictidae, Halictus, Seladonia, Asia.
\end{abstract}

\section{Halictus (Seladonia) smaragdulus Vachal}

(Figs. 25: A-E, 26: A-E, 27: A-H)

Halictus smaragdulus Vachal, 1895, Ann. Soc. esp. Hist. nat., (2)24: 150 [male, Spain: Sevilla].

Halictus (Seladonia) smaragdulus: Ebmer, 1978, Linzer biol. Beitr., 10: 24; Ebmer, 1988, Senckenbergiana biol., 68: 347-349.

Halictus barcelonicus Pérez, 1903, Esp. nouv. mellif.: 44; P.-v. Soc. Linn. Bordeaux, 58 :

* Contribution from the Entomological Laboratory, Faculty of Agriculture, Kyushu University, Fukuoka (Ser. 5, No. 73). 
211 [female, Spain: Barcelona].

Halictus smaragdulus forma vinulus Blüthgen, 1923, Arch. Naturg., A89, (5): 297, 300

[female \& male, Italy: Sicilia].

Halictus morinellus Warncke, 1975, Polsk. Pismo ent., 45: 118-119 [female \& male, Turkey:

Horasan].

Halictus buteus Warncke, 1975, Polsk. Pismo ent., 45: 119 [female, Turkey: Sile].

\section{Redescription.}

Female. Body: $5.20-6.80 \mathrm{~mm}$, fore wing with tegula $3.10-5.00 \mathrm{~mm}(\mathrm{n}=10)$.

Color: Generally dark, weakly golden green reflections on face, mesoscutum and scutellum; non-metallic parts brownish black; mandible with apical half reddened; flagellum beneath yellowish brown, scape and pedicel blackish brown; lateral lobe of pronotum

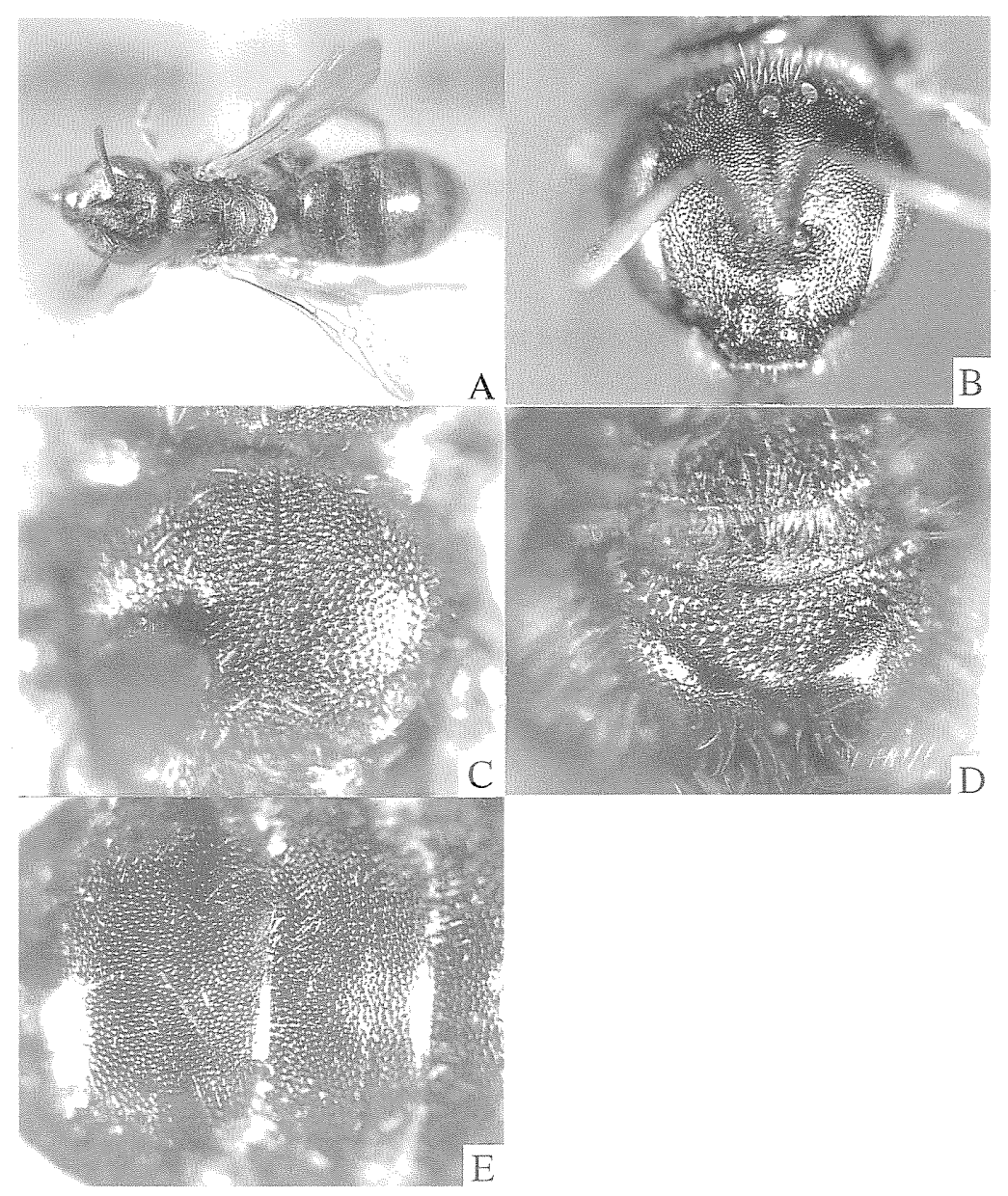

Fig. 25: A - E. Halictus (Seladonia) smaragdulus Vachal, female. A: general habitus; B: head in frontal view; C: mesoscutum; D: propodeum; E: metasomal terga. 
yellow apically; tegula yellowish brown transparent; veins and pterostigma brownish yellow; femur chestnut brown, apical part of femur and apical and basal parts of tibia yellow, tarsi yellowish brown; tibial spurs yellowish; posterior margins of metasomal terga yellowish brown.

Pilocity: Generally yellowish to pale fulvous, 120 - $150 \mu$ on vertex, $120-130 \mu$ on face, $210-230 \mu$ on pronotum, $130-150 \mu$ on mesoścutum centrally, $150-180 \mu$ on scutellum marginally and sternal scopa $220-250 \mu$; tomental hairs behind lateral lobe of pronotum small; tegula with yellowish short hairs anteriorly; basilateral patch on T1 small; metasomal terga with broad apical bands of pale yellowish hairs, T1 interrupted, T2- 4 complete, surface with short pale yellowish hairs.

Structure: Head: HW : HL $=1.77: 1.65 ; \mathrm{HW}: \mathrm{MsW}: \mathrm{MtW}=1.77: 1.50: 1.95$. Vertex round in frontal view, shiny and smooth, PP fine. Mean ratio of IOD : OOD : OCD $=0.34$ : $0.38: 0.15$. Eyes short in lower interorbital distance, MOD $:$ UOD $:$ LOD $=1.28: 1.24$ : 1.16. Postocellar PP, $15-25 \mu \varnothing$, rather ill-defined, ocellocular PP, $15-28 \mu \varnothing$, IS $=0.1-0.3$ rarely 1 , postocellar depression relatively conspicuous. Frons distinctly convex; frontal carina relatively short, shorter than carina-ocellus distance. Paraocular area with epistomal angle roundly obtuse, lower margin slightly ascending laterad, PP, $15-20 \mu \varnothing$, IS $=0.1-1$ above, $20-28 \mu \emptyset$, IS $=0.2-1$ below. Supraclypeus slightly higher than clypeus, with PP, $10-25 \mu \varnothing$, IS $=1-2.5$. Clypeus with marginal area weakly depressed, CPL : CAL : APL = $0.44: 0.62: 0.28$, smooth and shiny with sparse PP, $15-30 \mu \varnothing$, IS $=0.2-2$. Genal area narrower than eye, $\mathrm{EW}: \mathrm{GW}=0.43: 0.44$, surface with small PP, rather shiny and smooth. Mesosoma. Pronotum with many lateral ridges acute but not extending below; lateral surface coriaceous and shagreened. Mesoscutum smooth and shiny with distinct PP, $15-28 \mu \varnothing$, IS = 0.2 - 1, scutellum medially very weakly depressed longitudinally, with denser and smaller PP anteromedially. Scutellum : metanotum : propodeal dorsum $=0.30: 0.21: 0.26$. Propodeal side homogeneously tessellate with indistinct sparse PP, with lineolation below; propodeal dorsum with enclosure slightly depressed, ridges irregular, occupying basal 3/4 rugosed, and apical 1/4 tessellate; lateral field weakly tessellate and weakly shiny, broadly impunctate except above; propodeal declivity with sparse PP. Tegula smooth broadly. Inner hind tibial spur with 4 - 5 relatively long and round-tipped teeth. Metasoma: T1 smooth and shiny with small, dense PP basally, $6-15 \mu$, IS $=0.2-2$, rather sparser PP on apical narrow area, IS 1 - 3 or more, T2, 3 with sparser and fine PP, $6-18 \mu \varnothing$, IS = $0.2-2.5$. Pygidial plate U-shaped. Metasomal sterna shagreened with small indistinct sparser PP.

Male. Body: $6.00-6.50 \mathrm{~mm}$, fore wing with tegula $3.70-4.20 \mathrm{~mm}(\mathrm{n}=2)$.

Color: As in female, non-metallic parts rather blackish; metasomal terga marginally blackish, not transparent; apical 1/3 of clypeus, labrum, central part of mandible yellow; tegula brownish yellow, transparent; apices of femora, tibiae except middle parts and all tarsi lemon yellow. 
Pilosity: As in female, relatively paler; tomental patch less developed; hairs $200-210 \mu$ on vertex, $200-230 \mu$ on face, $190-220 \mu$ on pronotum, $130-150 \mu$ on mesoscutum centrally, $180-200 \mu$ on scutellum marginally and sternal hairs posteriorly $200-270 \mu$; tegula with anterior hairs long; genal tomental patch weak; metasomal terga with apical bands of dull whitish hairs, broadly interrupted on T1, 2 and narrowly interrupted on T3, 4, surface with very short pale yellowish hairs.

Structure: Head: HW : HL = $1.54: 1.65$; HW : MsW : MtW $=1.54: 1.39: 1.21$. Vertex round in frontal view. Postocellar area with distinct PP, $15-20 \mu \varnothing$, IS $=0.3-2$, smooth and shining. Ocellocular area with similar PP distinct, $20-25 \mu \varnothing$, IS $=0.1-0.5$. Frons distinctly convex; frontal carina relatively short, shorter than carina-ocellus distance. Flagellar segments F1-3 L, F10 L and F 2W = 0.18: $0.22: 0.21: 0.19: 0.26$. Supraclypeus slightly convex, with PP $15-25 \mu$, medially, IS = $0.2-2$. Clypeus flat, with PP, 10 -

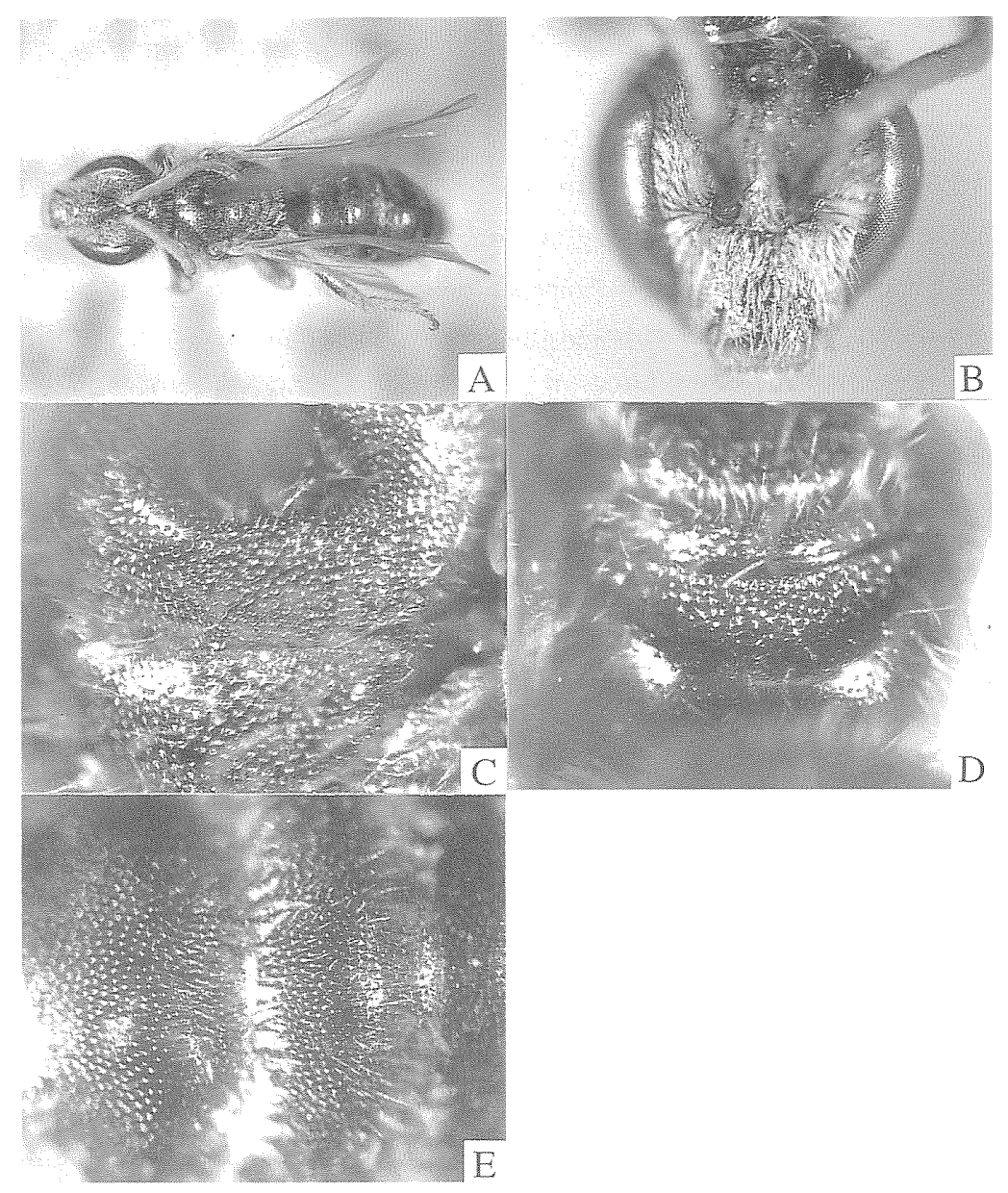

Fig. 26: A - E. Halictus (Seladonia) smaragdulus Vachal, male. A: general habitus; B: head in frontal view; C: mesoscutum; D: propodeum; E: metasomal terga. 
$30 \mu \varnothing$, IS $=0.3-2, \mathrm{CPL}: \mathrm{CAL}: \mathrm{APL}=0.36: 0.73: 0.27$, not much coarser and sparser below. Genal area narrower than eye, $\mathrm{EW}: \mathrm{GW}=0.50: 0.27$. Mesosoma: Pronotum with lateral ridges but not extending below, lateral surface smooth and shining. Mesoscutum smooth and shiny with distinct PP, $20-28 \mu \varnothing$, IS $=0.2-1.5$, scutellum medially not depressed longitudinally, with similar PP. Scutellum : metanotum $:$ propodeal dorsum $=$ $0.33: 0.17: 0.23$. Propodeal side with relatively dense and distinct PP, $20-28 \mu \varnothing$, IS on above $=0.2-1.5$, below more. Propodeal dorsum with enclosure mildly depressed, with stronger ridges fairly irregular, apical area and lateral field smooth and shining, with rather sparse PP. PP of propodeal declivity above distinct and sparser, $20-25 \mu$ ø. Hind tibia : hind basitarsus : hind distitarsus $=0.80: 0.57: 0.60$. Metasoma: $\mathrm{T} 1$ smooth and shiny all over with anterior declivity with rather sparse PP, disc with dense $10-20 \mu \varnothing$, IS $=0.5$ 2.3 , rarely more than 3 , marginal area with very sparse PP; T2, 3 similar to T1 with PP a little roughened. T7 not elongated, smooth and shiny with round apex without carination. S8 medially mildly projecting, apex not sharply pointed. Genitalia: Gonostylus subbasally flat, apex conspicuously dilated outwardly, tufted hairs relatively short; modified hairs short and distinctly geniculate; dorsal lobe long and medial part dilated outwardly; ventral lobe shorter than main body, with sparse hairs only apically.

Specimens examined: IRAN: 2 females, Elburs, $75 \mathrm{~km}, \mathrm{~S}$ Chalus, $2400 \mathrm{~m}, \mathrm{~N}$ Passhöhe, 13. vii. 1977 (A. W. Ebmer); 2 females, Elburs, $60 \mathrm{~km}$, S Chalus, 1600 m, 13. vii. 1977 (A. W. Ebmer); 2 females, Elburs, 40 km, S Shahpasand, Tilabad, 1600 m, 16. vii.1977 (A. W. Ebmer); 1 female, Elburs, 75 km, S Chalus, 2400 m, N Pabhohe, 24. vii. 1977 (A. W. Ebmer); 1 female, Elburs, 30 km, S Chalus, 1500 m, 27. vii. 1977 (A. W. Ebmer); 5 females, Kaspi-See, Niederung, 0 m, Babol-Sar, 14. vii. 1977 (A. W. Ebmer); 3 females, Kopet Dagh, 30 km, N Quchan, Passhöhe, 2000 m, 18. vii. 1977 (A. W. Ebmer); 1 female, Oberhalb, Zoshk, bei Shandiz, W Mashad, 1600-2000 m, 19. vii.1977 (A. W. Ebmer); 1 female, Elburs, Damavand-Gebiet, Polur, 2000 m, 21. vii, 1977 (A. W. Ebmer). Old YUGOSLAVIA: Insel: Cres-Losinj, Osor (A. W. Ebmer): 3 females, 15. vii. 1971; 3 females, 16. vii. 1971; 3 females, 17. vii. 1971; 1 male and 5 females, 20. vii. 1971; 14 females, Dalmatien Dubrovnik, 17-25. vii. 1968 (A. W. Ebmer). GREECE: Rhodos Is., Akropolis (J. Klimesch):1 male, 27-28. ix. 1972; 1 male, 29-30. ix. 1972; 6 females, Krim Alusta, 15. vii. 1969 (Y. W. Dolin). AFRICA: MORROKO: Hoher Atlas: 7 females, Agaiouar, 1500 m, 10. vii. 1975 (A. W. Ebmer); 3 females, Tichka-Pass-Süd, 2000 m, 13. vii. 1975 (A. W. Ebmer); 1 female, Azrou, 1660 m (Zedernwälder), 17. vii. 1975 (A. W. Ebmer); 1 female, Ibel Sarhro (Sahara Atlas Ait Saoun) 1200 m, 14. vii. 1975 (A. W. Ebmer).

Remarks: The female of this species is similar to Halictus semitectus Morawitz. But it is recognized by the metasomal tergum 4 not completely covered with pale yellowish hairs medially, the clypeus less convex, and the pronotum with many lateral ridges.

Distribution: Kyrgyzstan; Iran; Afghanistan; Pakistan; Turkey; Cyprus; European Russia; 

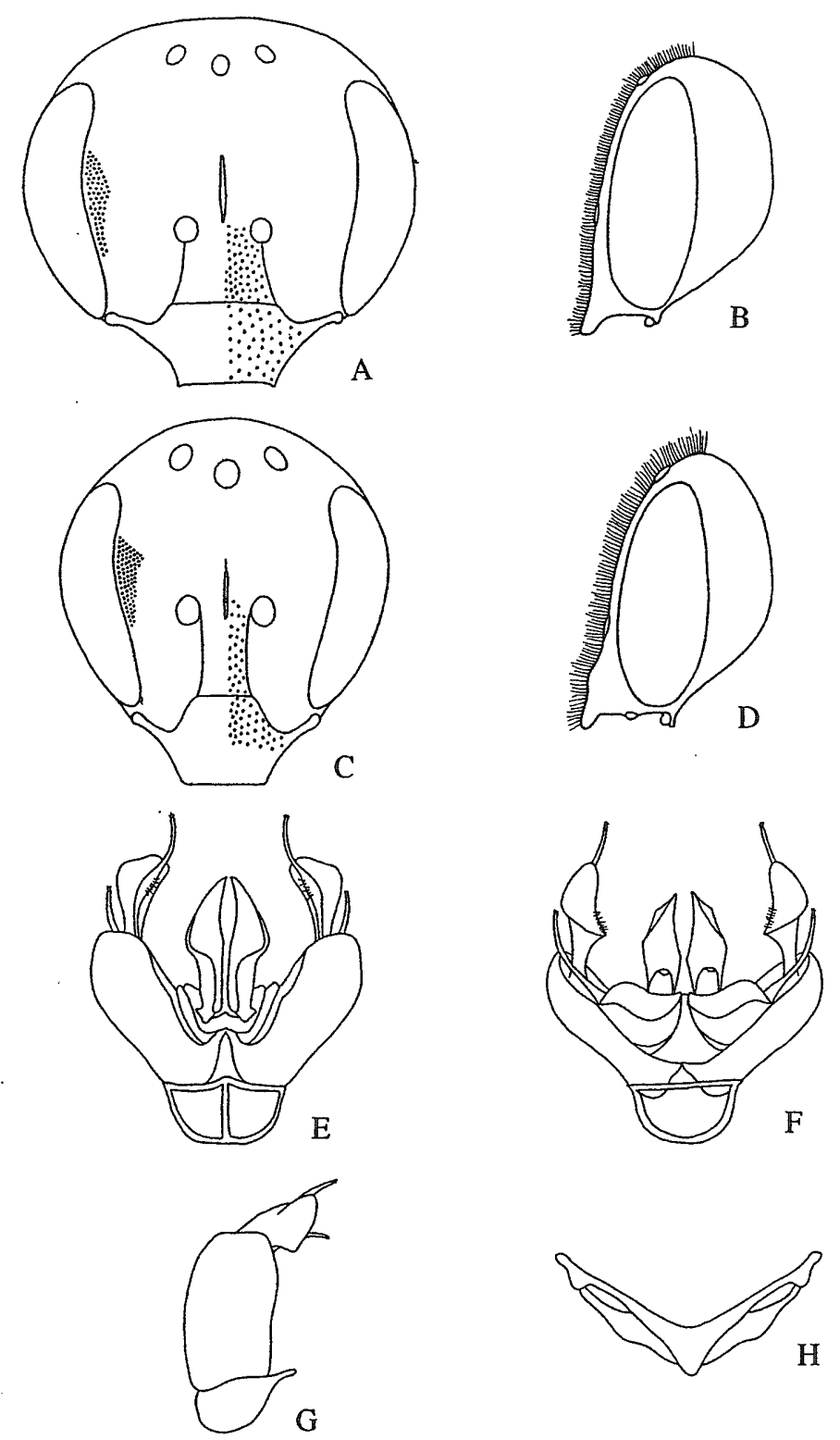

Fig. 27: A - H. Halictus (Seladonia) smaragdulus Vachal. A: frontal view of the head, female; B: lateral view of the head, female; $\mathrm{C}$ : frontal view of the head, male; $\mathrm{D}$ : lateral view of the head, male; E: dorsal view of the male genitalia; F: ventral view of the male genitalia; G: right lateral view of the genitalia; $\mathrm{H}$ : sterna 7 and 8 of the male. 
Ukraina; Romania; Hungary; Austria; Germany; France; Switzerland; Italy, Sardinia Is., Corsica Is., Sicilia Is.; old Yugoslavia; Albania; Greece, Rodhos Is., Kriti Is.; Spain; Portugal; Morroko.

Floral association: Not available.

\section{Halictus (Seladonia) semitectus Morawitz}

(Fig. 28: A-E, 29: A-B)

Halictus semitectus Morawitz, 1873, Hor. Soc. ent. Ross., 10 (1874): 172-173 [female \& male, Kaukasus]; Dalla Torre, 1896, Cat. Hym., 10: 82; Blüthgen, 1934, Ark. Zool., 27A (13): 3 [Notes].

Halictus (Seladonia) semitectus: Ebmer, 1982, Mitt. zool. Mus. Berlin, 58: 202; Ebmer, 1988, Senckenbergiana biol., 68: 350-351.

\section{Redescription.}

Femalle. Body length $5.50-5.70 \mathrm{~mm}$. Fore wing with tegula $3.60-3.90 \mathrm{~mm}(\mathrm{n}=3)$.

Color: Generally paler, weakly golden green reflections, non-metallic parts rather brownish than blackish; flagella below dark brown, scape and pedicel blackish; lateral lobe of pronotum apically pale brown to yellow; tegula transparent, pale brown; femur chestnut brown, apices of femur and tibia yellow, tibial spur brownish yellow; posterior margins of metasomal terga yellowish brown, transparent.

Pilosity: Generally paler, non tomental hairs pale fulvous and shorter, $150-160 \mu$ on vertex, $170-180 \mu$ on face, $170-190 \mu$ on gena, $180-200 \mu$ on pronotum, $90-100 \mu$ on mesoscutum centrally and $90-110 \mu$ on scutellum marginally, sternal hairs posteriorly 200 $230 \mu$; tomental hairs behind lateral lobe of pronotum small; basilateral patch on T1 small.

Structure: Head: HW : HL = $1.46: 1.50 ; \mathrm{HW}: \mathrm{MsW}: \mathrm{MtW}:=1.46: 1.50: 1.67$. Vertex flat in frontal view, shiny and smooth, with roughened PP. Mean ratio of IOD : OOD : $\mathrm{OCD}=0.23: 0.30: 0.11$; OCD very short. Eyes conspicuously short in lower interorbital distance; MOD : UOD : LOD = $1.07: 0.96: 0.77$. Postocellar PP, 10 - 18 $\mu$, IS broad, smooth and shining; ocellocular PP, $17-20 \mu \varnothing$, IS $=0.1-1$. Frons mildly but distinctly convex, frontal carina relatively short, usually shorter than carina-ocellus distance. Paraocular area with epistomal angle roundly obtuse, lower margin slightly ascending laterad, PP $18-22 \mu \varnothing$, IS $=0.2-1$, sometimes 1.5 or more above, $20-22 \mu \varnothing$, below, IS = 0.1 - 1. Supraclypeus higher than clypeus, with PP sparse, $10-25 \mu \varnothing$. Clypeus with marginal area strongly depressed, CPL : CAL : APL $=0.32: 0.60: 0.17$, with PP very sparse 10 $25 \mu \varnothing$, IS $=1-5$ or more. Gena slightly wider than eye, $\mathrm{EW}: \mathrm{GW}=0.33: 0.37$ on average. Mesosoma: Pronotum without lateral ridge, lateral surface coriaceous and shagreened. Mesoscutum smooth and shiny, with distinct PP, $15-25 \mu \varnothing$, IS = $1-3$, scutellum medially 
not depressed longitudinally, with PP $10-25 \mu$, sometimes $30 \mu ø$, IS $=0.1-3.5$. Propodeal side homogeneously tessellate below without lineolation, with very weak and sparse PP. Scutellum : metanotum : propodeal dorsum $=0.34: 0.20: 0.29$. Propodeal dorsum with enclosure mildly depressed, ridges irregular, occupying nearly all over; lateral field nearly smooth to weakly tessellate and shiny, broadly impunctate above; propodeal declivity very weakly tessellate and shiny with sparsè PP. Tegula with anterior hairs short, surface shagreened. Inner hind tibial spur with 4 - 5 relatively long and round-tipped teeth issuing rather perpendicularly. Metasoma. T1 smooth and shiny with small, rather dense PP basally, 8 - 15 $\varnothing$, IS $=1-3$, sparser PP on apical narrow area; T2, 3 weakly tessellate with rather sparser PP, 8 - 15 $\varnothing$ ø, IS $=0.5$ - 2.5 or more. Pygidial plate U-shaped. Metasomal sterna with moderately sparser PP.

Specimens examined: MONGOLIA: 2 females, St. Ic. 1, 24. vii. 1979, MVR-Exped.

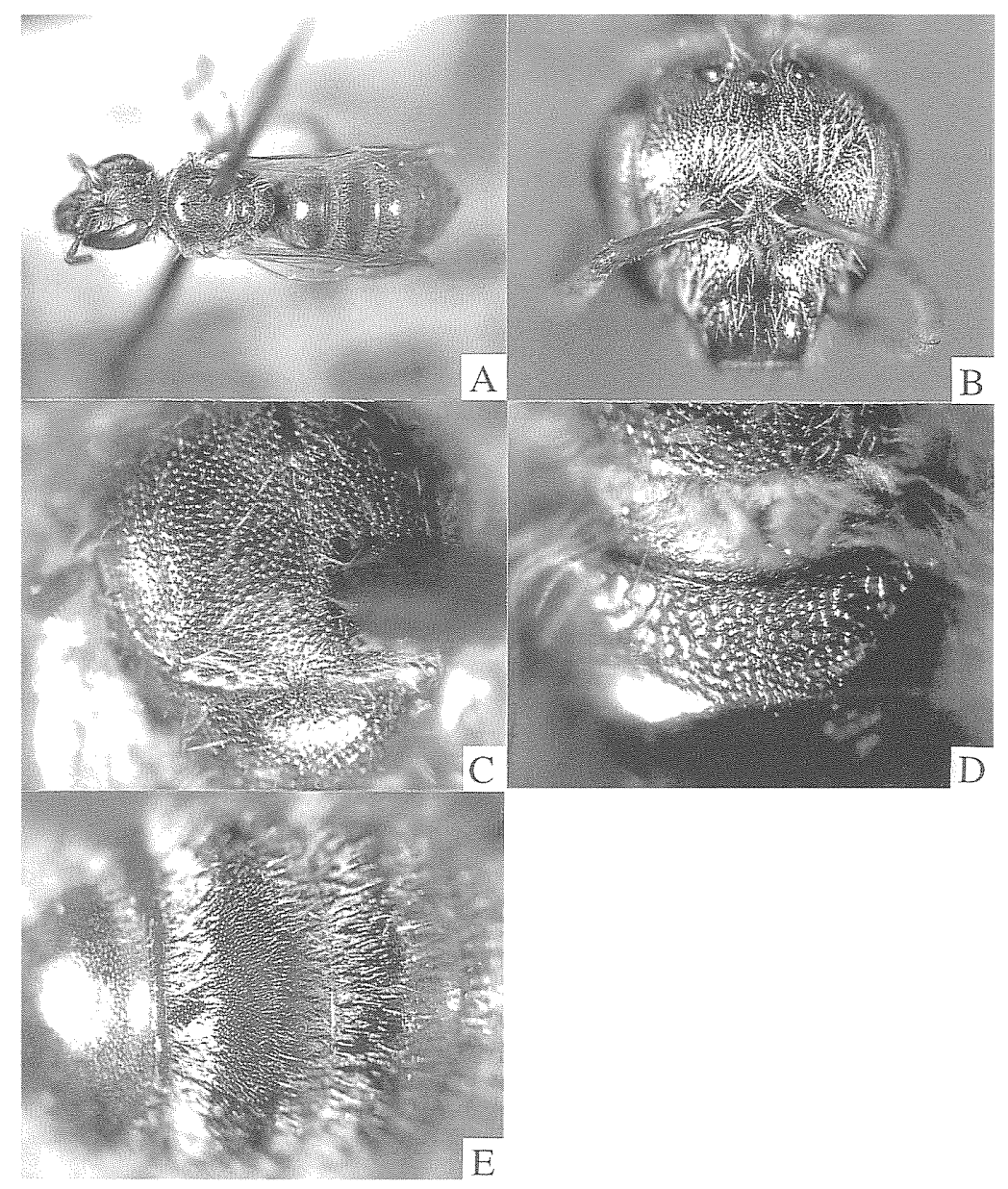

Fig. 28: A - E. Halictus (Seladonia) semitectus Morawitz, female. A: general habitus; B: head in frontal view; C: mesoscutum; D: propodeum; E: metasomal terga. 

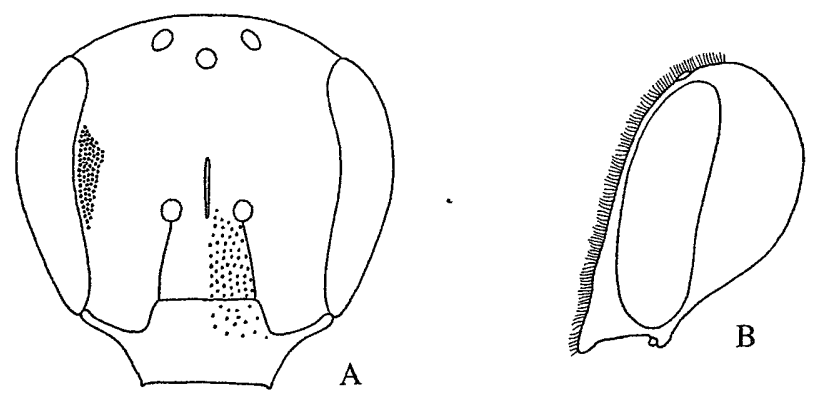

Fig. 29: A - B. Halictus (Seladonia) semitectus Morawitz. A: frontal view of the head, female; B: lateral view of the head, female.

1979, Bajanchongor Aimag, Ich-bogd, 25 km S, Bogd, S-Ufer Orognuur, Belfläche, 1350 m NN (Dorn); 1 female, MVR, Uvs-Aimag, Charchira-ul, $30 \mathrm{~km}$ S Ulangom, Umbeg, Kurort.

Remarks: The female of this species is similar to Halictus smaragdulus Vachal, and Halicts mongolicus Morawitz. But it is recognized from smaragdulus by the metasomal tergum 4 completely covered with pale fulvous hairs medially, the clypeus distinctly convex, and the pronotum without lateral ridges, and from mongolicus Morawitz by the head longer than broad, the eyes with inner margins convergent below, and the frontal carina shorter and the pronotum without lateral ridges.

This species was described from Kaukasus by Morawitz and shows wide distribution from Mongolia to middle Europe.

Distribution: Mongolia; Afghanistan; European Russia; Armenia; Ukraina; Poland; Hungary; Austria; old Yugoslavia.

Floral association: Not available.

\section{Halictus (Seladonia) mongolicus $\mathbf{M}$ orawitz}

(Figs. 30: A-E, 31: A-E, 32: A-H)

Halictus mongolicus Morawitz, 1880, Bull. Acad. imp. Sc. St. Petersbourg 26: 365- 366 [female, Mongolia] ; Blüthgen, 1929, Konowia, 8: 78 - 80 [male].

Halictus (Seladonia) mongolicus: Ebmer, 1982, Mitt. zool. Mus. Berlin, 58: 202; Ebmer, 1988, Senckenbergiana biol., 68: 350. 


\section{Redescription.}

Female. Body: 4.75 - $5.85 \mathrm{~mm}$, fore wing with tegula 3.60 - $3.90 \mathrm{~mm}(\mathrm{n}=9)$.

Color: Generally clear, green reflections, especially on face, mesoscutum and scutellum, apical margin of clypeus dark red; non-metallic parts rather brownish than blackish; flagellum beneath yellowish brown, scape and pedicel blackish; lateral lobe of pronotum yellow apically; tegula yellow transparent; veins and pterostigma yellowish brown; femur and tibia brownish, tarsi yellowish; tibial spurs yellow; metasomal terga reddened; posterior margins of metasomal terga yellowish transparent.

Pilocity: Generally dull white, $150-200 \mu$ on vertex, $200 \mu$ on face, $250-280 \mu$ on gena, $200-250 \mu$ on pronotum, $170-200 \mu$ on mesoscutum centrally, $180-230 \mu$ on scutellum marginally and sternal scopa $200-280 \mu$; tomental hairs behind lateral lobe of pronotum small; tegula with dull whitish hairs anteriorly, relatively long; basilateral patch on $\mathrm{T} 1$

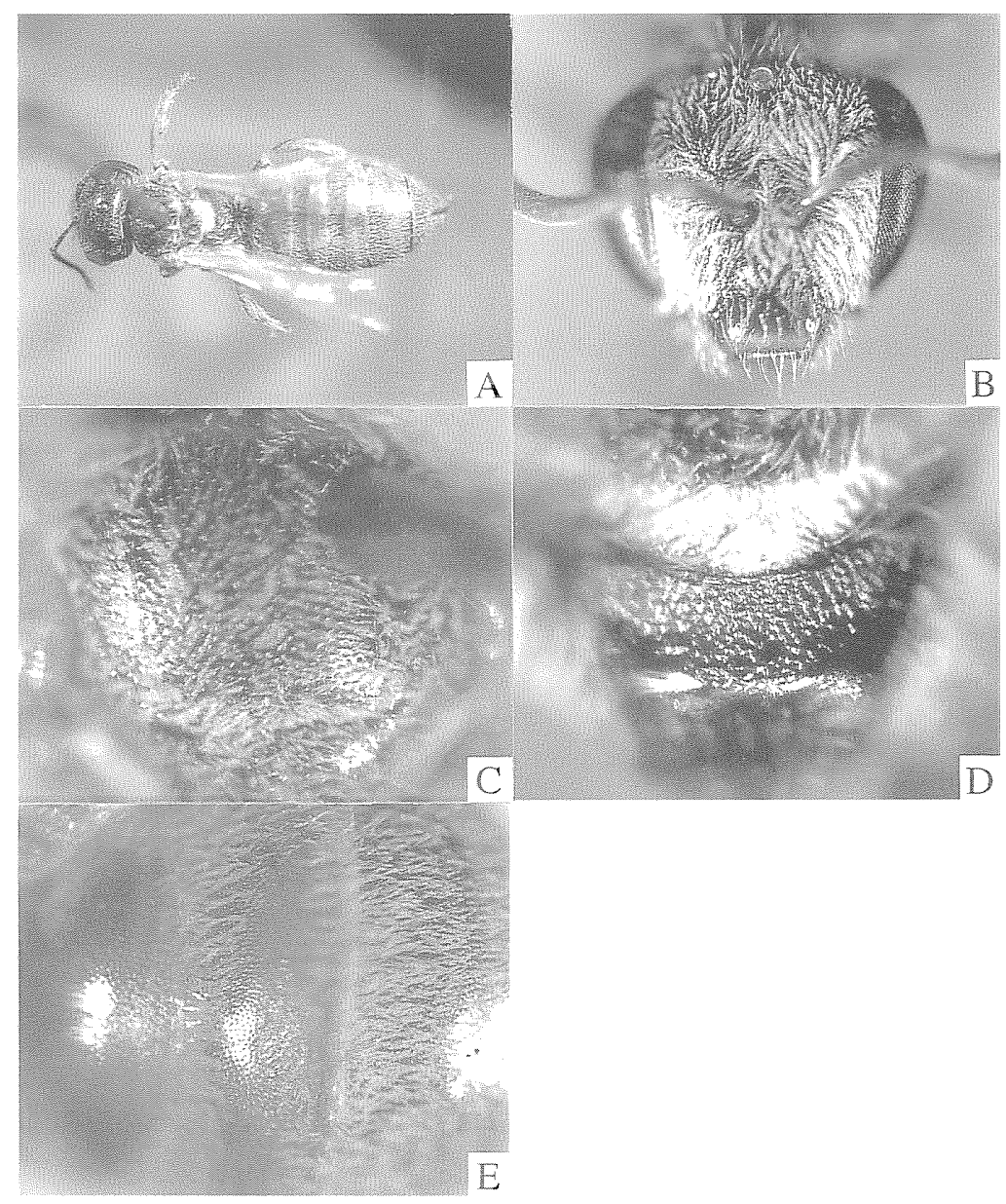

Fig. 30: A - E. Halictus (Seladonia) mongolicus Morawitz, female. A: general habitus; B: head in frontal view; C: mesoscutum; D: propodeum; E: metasomal terga. 
moderate; T1 with broad apical bands of dull white hairs complete, T2-4 with apical bands of dull white hairs, complete, surface with dense, dull white hairs.

Structure: Head: HW : HL = $1.43: 1.36 ; \mathrm{HW}: \mathrm{MsW}: \mathrm{MtW}=1.43: 1.47: 1.73$. Vertex round in frontal view, shiny and smooth, faintly concave medially. Mean ratio of IOD : OOD $:$ OCD $=0.23: 0.21: 0.19$. Eyes with inner margins subparallelled; MOD : UOD : LOD $=1.07: 0.86: 0.83$. Postocellar PP, 7 - 28 4 ø, IS smooth and shiny, ocellocular PP, 5 $20 \mu \varnothing$, IS $=0.1-1.5$, postocellar depression relatively conspicuous. Frons distinctly convex; frontal carina relatively long, longer than carina-ocellus distance. Paraocular area with epistomal angle roundly obtuse, lower margin slightly ascending laterad, PP, 15 $20 \mu \varnothing$, IS $=0.2-1.5$ above, $20-22 \mu \varnothing$, IS $=0.2-1$ below. Supraclypeus notably higher than clypeus, with PP, $10-25 \mu \varnothing$, IS $=0.5-2.0$. Clypeus flat, $\mathrm{CPL}: \mathrm{CAL}: \mathrm{APL}=0.29$ : $0.56: 0.22$, smooth and shiny, with PP very sparse in basal area, $15-30 \mu \varnothing$, IS $=1-3$ or more. Genal area broader than eye, EW : GW $=0.33: 0.40$, surface with small PP, shiny and smooth. Mesosoma: Pronotum with lateral ridge acute but not extending below; lateral surface coriaceous and shagreened. Mesoscutum smooth and shiny with distinct PP, 15 $25 \mu \varnothing$, IS $=0.2-1.5$, scutellum medially not depressed longitudinally, with PP relatively sparse anteromedially. Scutellum : metanotum : propodeal dorsum $=0.31: 0.19: 0.29$. Propodeal side smooth and shiny with sparse PP, with lineolation below; propodeal dorsum with enclosure slightly depressed, ridges irregular, rugosed all over; lateral field weakly tessellate and shiny, broadly impunctate except above; propodeal declivity weakly tessellate with sparse PP. Tegula nearly smooth broadly. Inner hind tibial spur with 2 - 3 relatively long and round-tipped teeth. Metasoma: T1 smooth and shiny with small, dense PP basally, $6-12 \mu \varnothing$, IS $=0.5-2.5$, sparser PP on apical narrow area; T2-4 a little more roughened with sparser PP, $6-10 \mu \varnothing$, IS $=0.3-2.5$. Pygidial plate U-shaped. Metasomal sterna weakly tessellate with small indistinct PP.

Malle. Body: 4.75 - $5.85 \mathrm{~mm}$, fore wing with tegula $3.54-3.90 \mathrm{~mm}(\mathrm{n}=4)$.

Color: As in female, non-metallic parts rather brownish than blackish; flagellum beneath yellowish brown, scape and pedicel blackish brown; apical 1/4 of mandible yellow; lateral lobe of pronotum yellow apically; tegula yellow transparent; veins and pterostigma yellowish brown; femur brownish; apical part of femur, tibia, tibial spur and tarsi yellowish; metasomal terga brown, posterior margin yellowish brownish, transparent.

Pilocity: Relatively paler and tomental patch well developed as in female; hairs 150 $200 \mu$ on vertex, $190-210$ on face, $200-250 \mu$ on pronotum, $170-200 \mu$ on mesoscutum centrally, $260-290 \mu$ on scutellum marginally, and sternal hairs $130-150 \mu$; metasomal terga with apical bands of dull white hairs, T1-3 interrupted, T4 complete, surface with very short and sparse dull white hairs.

Structure: Head: $\mathrm{HW}: \mathrm{HL}=1.29: 1.37 ; \mathrm{HW}: \mathrm{MsW}: \mathrm{MtW}=1.29: 1.23: 1.19$. Vertex slightly convex in frontal view, shiny and smooth, postocellar PP fine, $7-20 \mu \varnothing$, IS $=0.3$ - 


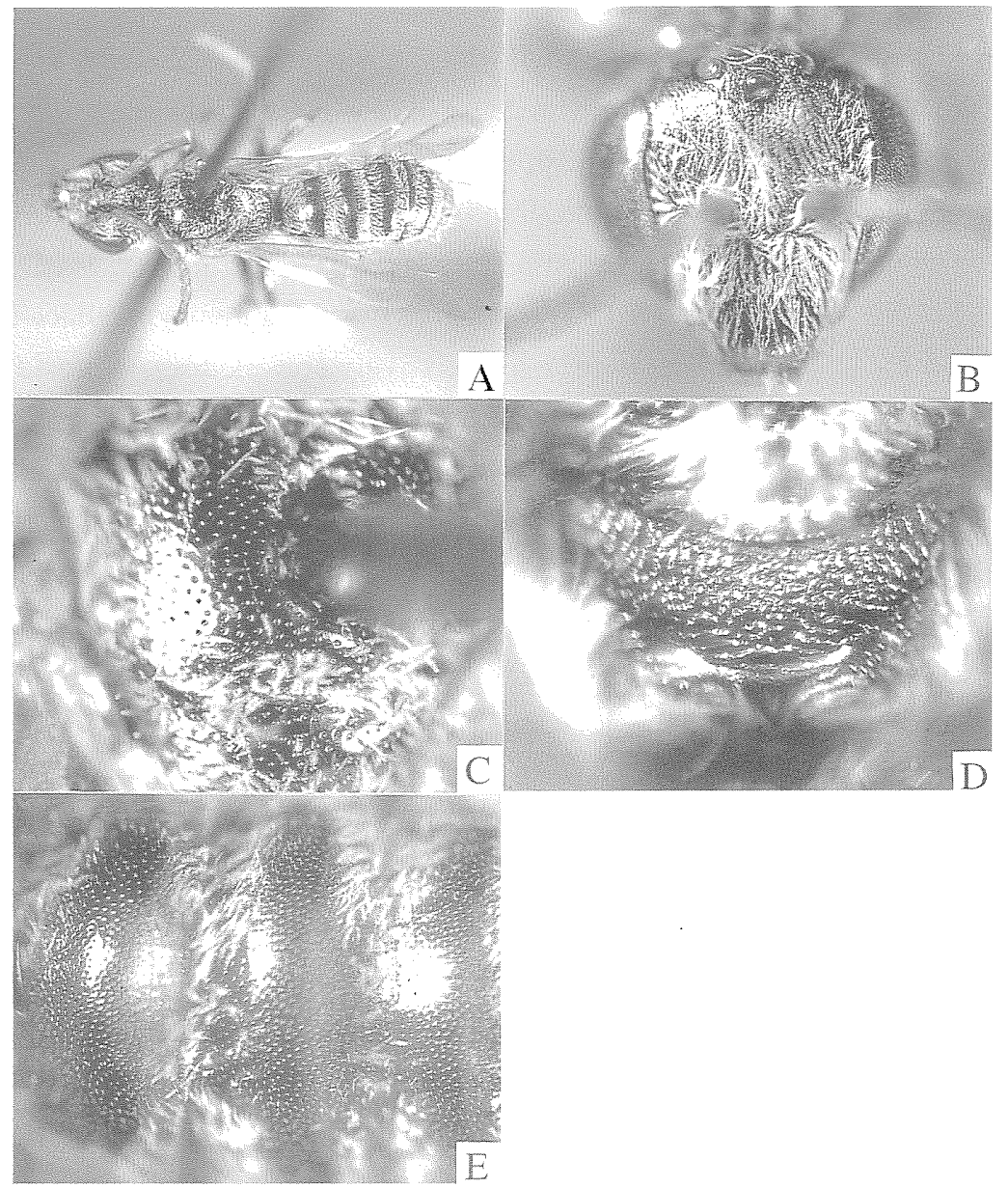

Fig. 31: $\mathbb{A}$ - E. Halictus (Seladonia) mongolicus Morawitz, male. A: general habitus; B: head in frontal view; C: mesoscutum; D: propodeum; E: metasomal terga.

3.5, ocellocular PP distinct, $5-20 \mu ø, \mathrm{IS}=0.1-3$. Flagellum very long, flagellar segments F1-3 L : F10 L and F2 W $=0.12: 0.17: 0.15: 0.20: 0.13$. Supraclypeus mildly convex, smooth and shiny with PP irregular in size and distribution medially $15-20 \mu \varnothing$, IS $=0.3-1$. Clypeus medially convex, smooth and shiny with PP, $15-25 \mu \varnothing, \mathrm{IS}=0.2-2.5$ above, very sparse and IS smooth and shiny below. $\mathrm{CPL}: \mathrm{CAL}: \mathrm{APL}=0.35: 0.74: 0.23$. Genal area narrower than eye, $\mathrm{EW}: \mathrm{GW}=0.34: 0.30$. Mesosoma: Pronotum with lateral ridges acute but not extending below. Mesoscutum smooth and shiny with sparse PP, $10-25 \mu \varnothing$, IS $=0.2-2.5$, scutellum medially not depressed longitudinally, with distinctly sparse PP. Scutellum : metanotum : propodeal dorsum $=0.38: 0.17: 0.33$. Propodeal side smooth and shiny with PP, $15-25 \mu$ ø, relatively sparse, IS $=0.5-1$; propodeal enclosure strongly depressed with stronger ridges anastomosing; lateral field nearly smooth and shiny, narrowly impunctate above; propodeal declivity smooth and shiny with distinct PP. Tegula as in 

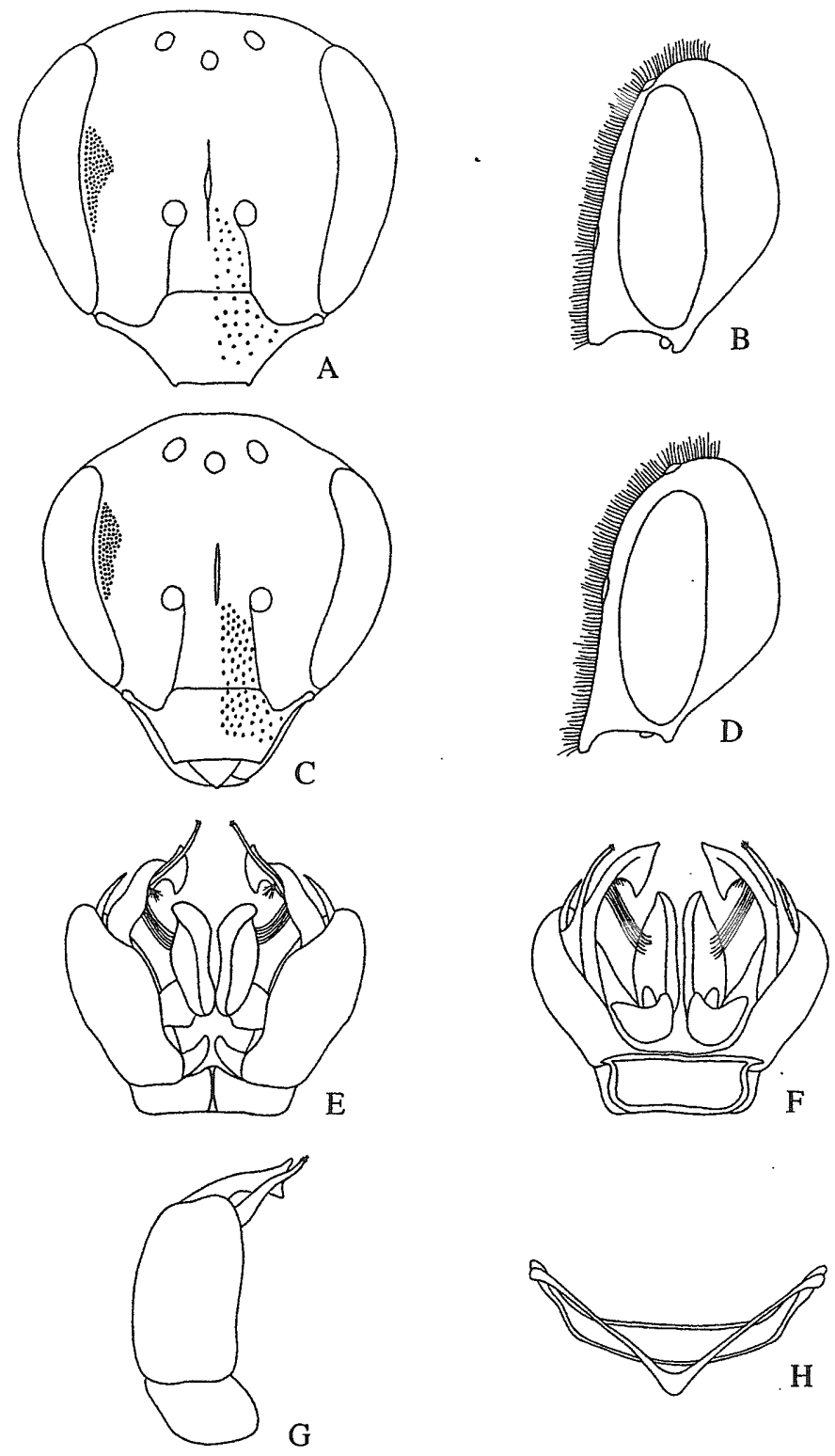

Fig. 32: A - H. Halictus (Seladonia) mongolicus Morawitz. A: frontal view of the head, female; B: lateral view of the head, female; $C$ : frontal view of the head, male; $D$ : lateral view of the head, male; E: dorsal view of the male genitalia; F: ventral view of the male genitalia; G: right lateral view of the genitalia; H: sterna 7 and 8 of the male. 
female. Hind tibia $:$ hind basitarsus $:$ hind distitarsus $=0.95: 0.73: 0.46$. Metasoma: T1 smooth and shiny with sparse PP, $5-8 \mu \varnothing$, IS $=0.2-2.5$ or more; T2, 3 similar to T1 with PP fine. T7 not elongated, smooth and shiny with round apex without carination. S8 mildly projecting medially, apex not sharply pointed. Genitalia: Gonostylus with apex pointed, sublaterally gently depressed, tufted hairs relatively stout; modified hairs of moderate long; dorsal lobe long and thin, longer than main body, ventral lobe slender, pointed apically, notably shorter than main body.

Specimens examined: MONGOLIA: 4 males and 9 females, St. Ib. 1., 24. vii. 1979, MVR-Exped. 1979, Bajanchongor Aimag, Ich- bogd, 20 km S, Bogd, S-Ufer Orognuur, Halbwüste, $1300 \mathrm{~m}$ NN (Dorn).

Remarks: The female of this species is similar to Halictus semitectus Morawitz. But it is separated by the head broader than long, the eyes with inner margins subparallelled, the

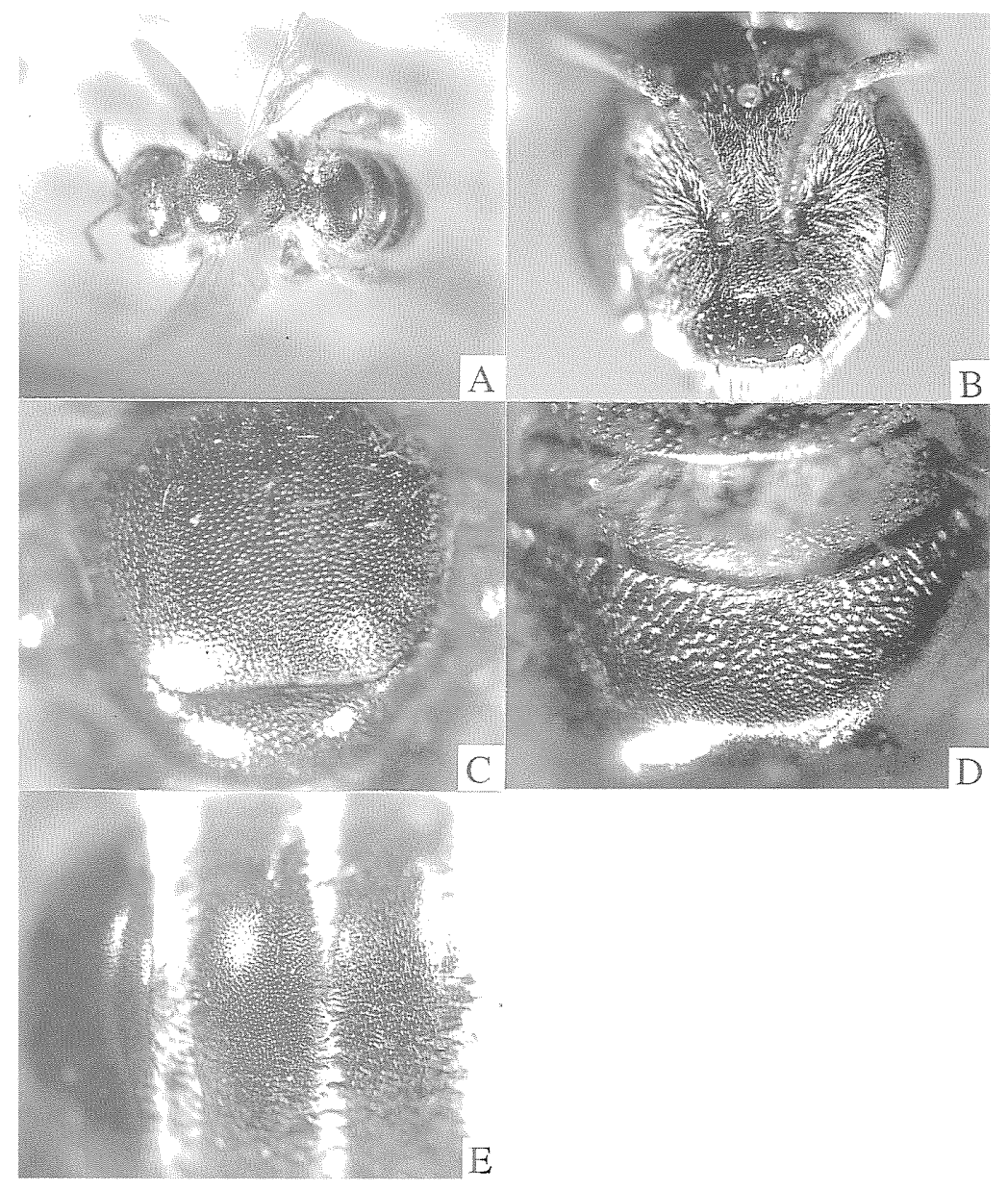

Fig. 33: A - E. Halictus (Seladonia) lucidipennis Smith, female. A: general habitus; B: head in frontal view; C: mesoscutum; D: propodeum; E: metasomal terga. 
frontal carina longer, and the metasoma terga reddened.

Distribution: Mongolia.

Floral association: Ebmer (1982) recorded Halymodendron.

\section{Halictus (Seladonia) lucidipennis Smith}

(Figs. 33: A-E , 34:"A-E, 35: A-H)

Halictus lucidipennis Smith, 1853, Catal. Hymen. Brit. Mus., 1: 62 [female \& male, N. India].

Halictus (Seladonia) lucidipennis: Ebmer, 1980, Linzer biol. Beitr., 12: 474, 483; Sakagami \& Ebmer, 1987, Linzer biol. Beitr., 19: 321-337 [redescription, female \& male]; Ebmer, 1988, Senckenbergiana biol., 68: 356.

Halictus varipes Morawitz in Fedcenko, 1876, Turkestan Mellifera, 2: 223-224 [female $\&$ male, Turkestan: Dzizak].

Halictus vernalis Smith, 1879, Descr. new spec. Hym. coll. Brit. Mus.: 30 [female, Ceylon]. Halictus niloticus Smith, 1879, Descr. new spec. Hym.: 32 [female, Sudan: white Nile]. Halictus magrettii Vachal, 1892, Bull. Soc. ent. France, 61: 137 [female, Sudan: Suakin]. Halictus dives Pérez, 1895, Esp. nouv. Mellif. Barbarie: 52 [female, Algeria: Biskra]. Halictus omanicus Pérez, 1907, Bull. scient. Fr. Belg., 41: 489-490 [female, Oman: Muscat]. Halictus varipes var. koptica Blüthgen, 1933, Bull. Soc. ent. Egypte, 17: 16-17 [female \& male, Egypet: Way to Giza].

Halictus sudanicus Cockerell, 1945, Ann. Mag. nat. Hist. (11) 12: 352 [female, Sudan: Shandi].

Halictus tokarensis Cockerell, 1945, Ann. Mag. nat. Hist. (11) 12: 352-353 [female, Sudan: Tukar].

Halictus dissensis Cockerell, 1945, Ann. Mag. nat. Hist. (11) 12: 353 [female, Sudan: Dissa].

Halictus medanicus Cockerell, 1945, Ann. Mag. nat. Hist. (11) 12: 354 [female, Sudan: Medani].

Halictus mogrensis Cockerell, 1945, Ann. Mag. nat. Hist. (11) 12: 355 [female, Sudan: Mogren].

Halictus tokariellus Cockerell, 1945, Ann. Mag. nat. Hist. (11) 12: 355 [female, Sudan: Tukar].

Halictus medaniellus Cockerell, 1945, Ann. Mag. nat. Hist. (11) 12: 356 [female, Sudan: Medani].

Halictus morinellus hyemalus Warncke, 1982, Boll. Mus. civ. Stor. nat. Venezia, 32 (1981): 134 [female, Iran: Bandar Abbas.]. 


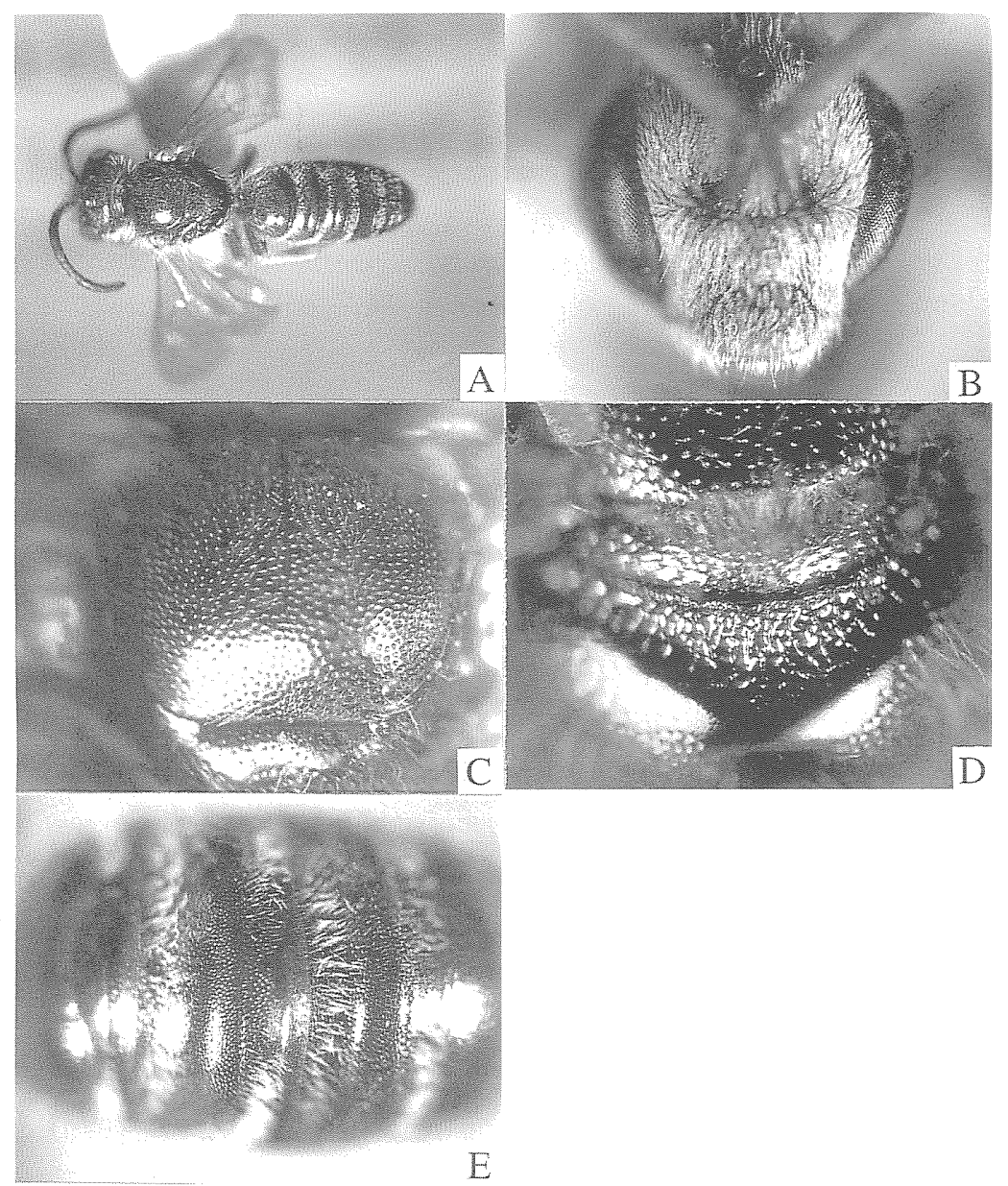

Fig. 34: A - E. Halictus (Seladonia) lucidipennis Smith, male. A: general habitus; B: head in frontal view; C: mesoscutum; D: propodeum; E: metasomal terga. Redescription. See Sakagami \& Ebmer (1987).

Specimens examined: INDIA: Bangalore: 1 female, Cubban Pv., 26. i. 1978; 6 females, U. Agr. Sci., 27. v. 1978 (Papilionac); Lonavla, W. Ghats: 1 female, 3. v. 1963 (Wain); 1 female, Lonavla 650 m, 30. v. 1963 (Wain); W. Ghats: 1 female, 4. v. 1963 (Khandala); 1 female, 7. i. 1964 (Ginhaga); 1 female, 9. ii. 1964; 1 female, Adyar, Madras, 12. viii. 1973 (Kudo). NEPAL: 1 female, Birgangi, 27. ii. 1968 (T. Kawamichi); 1 female, Trisuli, No. 1 West, 28. v. 1968 (T. Matsumura). SRI LANKA: 1 female, Southern Prov., Hiniduma, 2028. ii. 1958 (R. L. A. Pererea); Anu. Dist: Wildlife Soc. Bungalow, Hunuwilagama, Wilpattu, 10-19. iii. 1970 (Davis \& Rowe); 1 male and 1 female, Padaviya, 180', 2-8. xi. 1970 (O. S. Flint, Jr.); 3 females, Col. Dist, Colombo, 29-30. x. 1969 (P. B. Karunaratne); 1 female, Kan. Dist., 5 miNW Mahiyangana, 30. iii - 9. iv. 1971 (P. \& P. Spanger); 2 females, Pol. Dist., Pimburettawa 13, mi. S Mannampitiya, 9-12. xi. 1970, 1850' (O. S. Flint, Jr.); 1 

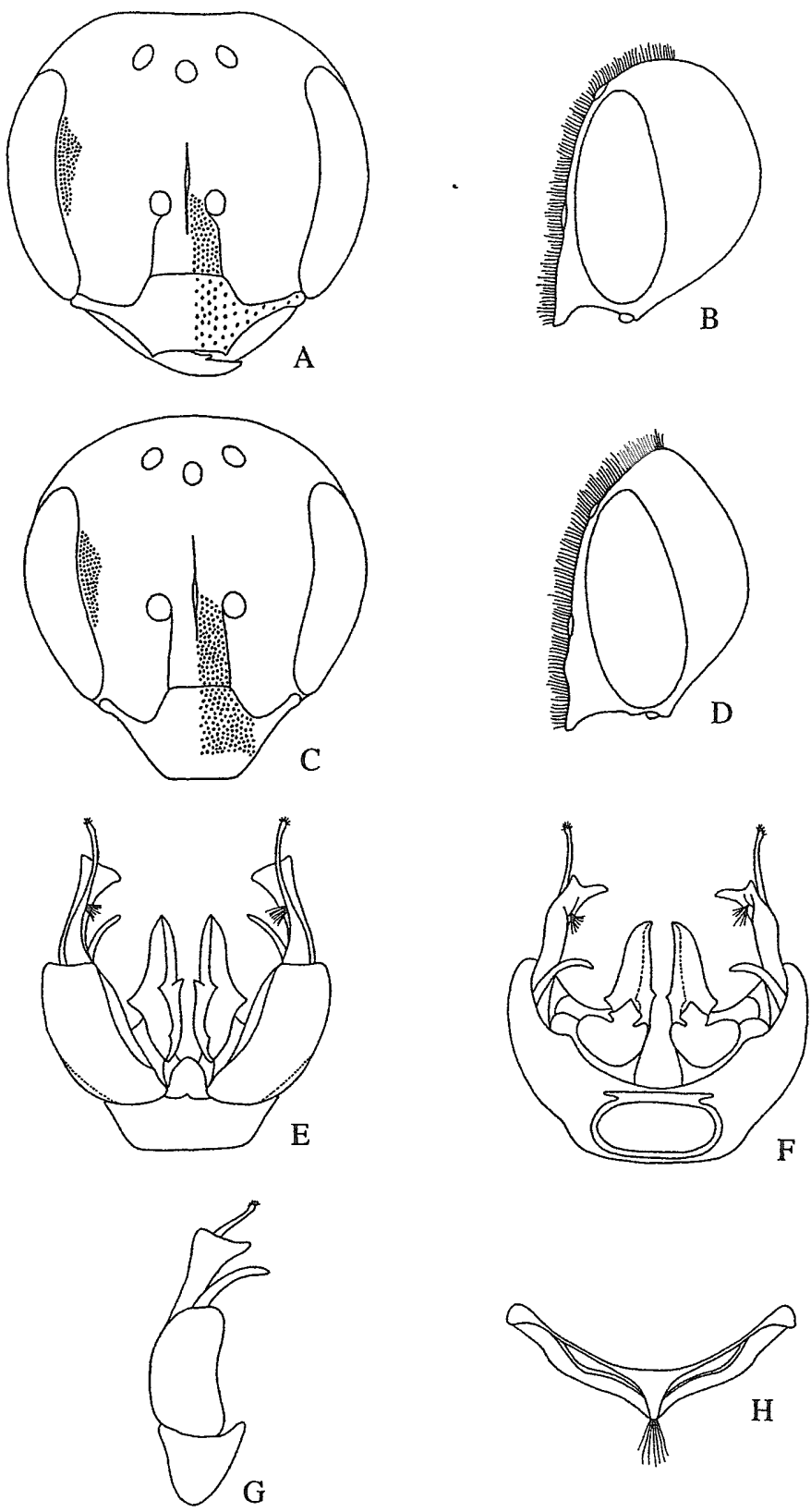

Fig. 35: A - H. Halictus (Seladonia) lucidipennis Smith. A: frontal view of the head, female; B: lateral view of the head, female; $\mathrm{C}$ : frontal view of the head, male; $\mathrm{D}$ : lateral view of the head, male; E: dorsal view of the male genitalia; F: ventral view of the male genitalia; G: right lateral view of the genitalia; $\mathrm{H}$ : sterna 7 and 8 of the male. 
female, Ham., Dist., Palatupana, Tank, 15-50 feet, 18-20. i. 1979 (K. V. Krombein, P. B. Karunaratne, T. Wijesinhe, S. Siriwardane, T. Gunawardane); 1 female, Tri. Dist. China, Bay, Ridge, Bungalow, 0-50 feet, 24-25. vii. 1978 (K. V. Krombein, T. Wijesinhe, V. Kulasekare, L. Jayawickrema); 1 female, Mon., Dist., Angunakolapelessa, 17-19. vii. 1978 (K. V. Krombein, T. Wijesinhe, L. Jayawickrema, V. Kulasekare); 2 males and 2 females, Mon., Dist., Angunakolapelessa, 100 meters, 21-23. i. 1979 (K. V. Krombein, P. B. Karunaratne, T. Wijesinhe, S. Siriwardane, T. Gunawardane); 1 male and 1 female, Mon., Dist., Mau Ara 100m., 10 mi. E. of Udawalawa, 24-26. ix. 1977 (K. V. Krombein, P. B. Karunaratne, T. Wijesinhe, M. Jayaweera); 1 female, Anu., Dist., Padaviya, 180' , 2-8. xi. 1970 (O. S. Flint, Jr.). THAILAND: 1 female, Skiracha, 15. xi. 1962 (A. Nagatomi). TURKMENISTAN: 7 females, Nebit-Dag, 25 km NW, Jebel, 28. iv. 1993 (M. Halada).

Remarks: This species is widely distributed in south and western Asia. It is separated from the other species in both sexes by the lateral ridges of pronotum extending below, and the posterior area of propodeal dorsum widely free from longitudinal ridges.

Distribution: India; Nepal; Sri Lanka; Thailand; Myanmar; Afghanistan; Pakistan; Turkmenistan.

Floral association: Not available.

\section{Halictus (Seladonia) varentzowi Morawitz}

(Fig. 36: A-E, 37: A-B)

Halictus varentzowi Morawitz, 1894, Hor. Soc. ent. Ross., 29 (1895): 67 (female \& male, Turkestan).

Halictus (Seladonia) varentzowi: Ebmer, 1988, Senckenbergiana biol., 68: 358.

\section{Redescription.}

Female. Body: 5.00 - $5.60 \mathrm{~mm}$, fore wing with tegula 3.60 - $4.35 \mathrm{~mm}(\mathrm{n}=6)$.

Color: Generally clear, weakly golden green reflections on face, mesoscutum and scutellum; non-metallic parts rather brownish than blackish; mandible with apical $2 / 3$ reddish brown; flagellum beneath brownish, scape yellowish brown basally, pedicel blackish; lateral lobe of pronotum yellow apically; tegula yellowish transparent; veins and pterostigma yellowish; femur brown, tibia and tarsi partly yellowish brown; tibial spurs yellow; metasomal terga reddish brown, posterior margins yellowish brown transparent.

Pilocity: Generally yellowish to pale fulvous, $110-130 \mu$ on vertex, $120-130 \mu$ on face, $180-250 \mu$ on pronotum, $90-110 \mu$ on mesoscutum centrally, $150-200 \mu$ on scutellum marginally and sternal scopa $200-230 \mu$; tomental hairs behind lateral lobe of pronotum small; tegula with yellowish short hairs anteriorly; basilateral patch on $\mathrm{T} 1$ small; metasomal terga with relatively narrow apical bands of yellowish white hairs. 




Fig. 36: A - E. Halictus (Seladonia) varentzowi Morawitz, female. A: general habitus; B: head in frontal view; C: mesoscutum; D: propodeum; E: metasomal terga.

Structure: Head: HW : HL = $1.51: 1.48 ; \mathrm{HW}: \mathrm{MsW}: \mathrm{MtW}=1.51: 1.27: 1.60$. Vertex flat in frontal view, shiny and smooth, with small fine PP. Mean ratio of IOD :OOD :OCD = $0.35: 0.31: 0.19$. Eyes with inner margins subparallelled, MOD $:$ UOD $:$ LOD $=1.06: 0.96$ : 0.89 . Postocellar PP, $10 \mu \varnothing$, IS $=0.3-3$, smooth and shiny, ocellocular PP, $10-15 \mu \varnothing$, IS = 0.5 - 5 or more. Frons distinctly convex; frontal carina relatively short, shorter than carina-ocellus distance. Paraocular area with epistomal angle roundly obtuse, lower margin slightly ascending laterad, PP, $8-18 \mu \varnothing$, IS $=0.2-1.5$ above, $10-20 \mu \varnothing$, IS $=0.2-2$ below. Supraclypeus slightly convex, with sparse PP, $10-15 \mu \varnothing$, IS $=1-10$. Clypeus slightly convex, $\mathrm{CPL}: \mathrm{CAL}: \mathrm{APL}=0.29: 0.51: 0.13$, smooth and shiny with very sparse PP, $8-15 \mu \varnothing$. Eyes distinctly broader than genal area, EW : GW $=0.43: 0.33$, surface with small sparse PP, shiny and smooth near eye and shagreened behind. Mesosoma: Pronotum with lateral ridges, surface weakly shiny and shagreened. Mesoscutum smooth 

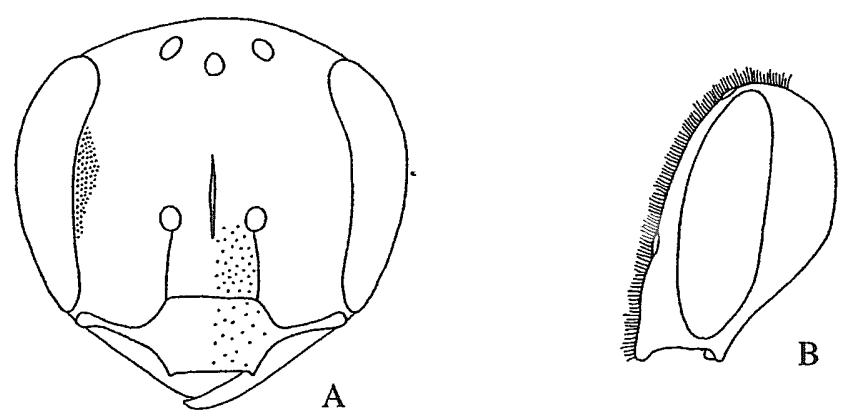

Fig. 37: A - B. Halictus (Seladonia) varentzowi Morawitz, A: frontal view of the head, female; B: lateral view of the head, female.

and shiny with distinct PP, $8-15 \mu \varnothing$, IS $=0.5-2.5$, scutellum medially not depressed longitudinally, with irregular, sparse PP anteromedially. Scutellum : metanotum : propodeal dorsum $=0.30: 0.16: 0.31$. Propodeal side homogeneously tessellate with indistinct PP, sparse; propodeal dorsum with enclosure nearly flat, ridges irregular, occupying basal $2 / 3$, and apical 1/3 smooth and shining, lateral field very weakly tessellate and weakly shiny, broadly impunctate except above; propodeal declivity weakly tessellate with weak, sparse PP. Tegula nearly smooth broadly. Inner hind tibial spur with $2-3$ relatively long and round-tipped teeth. Metasoma: T1 smooth and shiny with small PP, $6-8 \mu \varnothing$, IS $=1-2$ or more, sparser PP on apical narrow area, T2, 3 smooth to very weakly tessellate, with sparser PP, $5-8 \mu$ ø, IS = 1 - 3. Pygidial plate U-shaped. Metasomal sterna weakly tessellate with small indistinct PP.

Specimens examined: TURKMENISTAN: 6 females, Kopet-Dag, Kizil-Arvat, $50 \mathrm{~km}$ S, Chajagala, 17. v. 1993 (M. Halada).

Remarks: The female of this species is similar to Halictus placidulus Blüthgen. But it is recognized by the clypeus flat and the hairs on mesoscutum and metasomal terga not dense.

Distribution: Turkmenistan; old Turkestan.

Floral association: Not available.

\section{Halictus (Seladonia) placidulus Blüthgen}

(Fig. 38: A-E) 
Halictus placidulus Blüthgen, 1923, Arch. Naturg., 89A: 240 [female, China: Xinjiang]; Blüthgen, 1931, Mitt. zool. Mus., Berlin, 17: 395 (male). Halictus (Seladonia) placidulus: Ebmer, 1988, Senckenbergiana biol., 68: 358.

\section{Redescription.}

Female. Body $5.20 \mathrm{~mm}$, fore wing with tegula $3.67 \mathrm{~mm}(\mathrm{n}=1)$.

Color: Generally clear, face, mesoscutum and scutellum golden green reflections; nonmetallic parts rather brownish than blackish; mandible with apical half reddened; basal half of mandible and apical part of clypeus yellowish; flagellum beneath yellowish brown, scape and pedicel brown; lateral lobe of pronotum brownish yellow apically; tegula yellowish transparent; veins and pterostigma yellowish; femur yellowish brown, tibia,

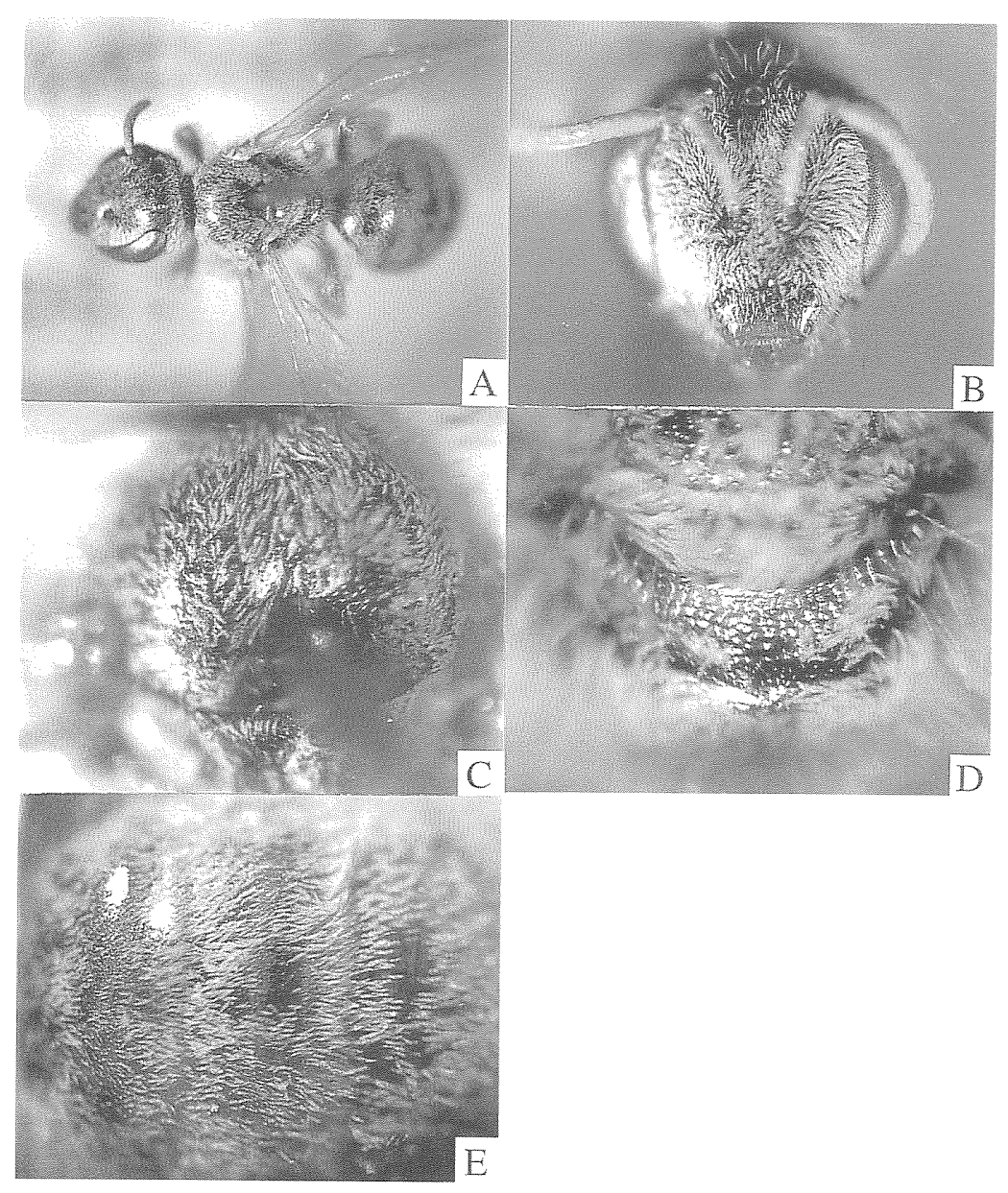

Fig. 38: A - E. Halictus (Seladonia) placidulus Blüthgen, female. A: general habitus; B: head in frontal view; C: mesoscutum; D: propodeum; E: metasomal terga. 
tarsi and tibial spurs yellowish; metasomal terga reddish brown, posterior margins yellowish transparent.

Pilocity: Generally yellowish white, decumbent, patch like hairs, $180-200 \mu$ on vertex, $160-180 \mu$ on face, $150 \mu$ on pronotum, $100-150 \mu$ on mesoscutum centrally, 130 $180 \mu$ on scutellum marginally and sternal hairs $170-200 \mu$; tomental hairs behind lateral lobe of pronotum small; tegula with yellowish white short hairs anteriorly; basilateral patch on $\mathrm{T} 1$ dense, large; metasomal terga with broad apical bands of yellowish white hairs, T1 interrupted, T2-4 complete; T1-4 with short and dense yellowish white hairs covering the surface.

Structure: Head: HW : HL $=1.39: 1.33$; HW $: \mathrm{MsW}: \mathrm{MtW}=1.39: 1.36: 1.47$. Vertex flat in frontal view, shiny and smooth with small PP. Mean ratio of IOD : OOD :OCD = $0.27: 0.19: 0.23$. Upper margin of eyes curved to inside, lower margin parallelled, MOD : UOD $:$ LOD $=1.06: 0.80: 0.83$. Postocellar PP, $10-15 \mu \varnothing$, IS smooth and shiny, ocellocular $\mathrm{PP}, 10 \mu \varnothing, \mathrm{IS}=0.2-1.5$, postocellar depression relatively conspicuous. Frons slightly convex; frontal carina relatively short, shorter than carina-ocellus distance. Paraocular area with epistomal angle roundly obtuse, lower margin slightly ascending laterad, with small PP, $7-12 \mu$ ø, IS $=0.5-1.5$ above, $8-15 \mu \varnothing$, IS $=0.3-1$ below. Clypeus area notably high and supraclypeus slightly higher than clypeus, with PP, $10-15 \mu \varnothing$, IS $=0.3-2$ on supraclypeus, 7 - $15 \mu \varnothing$, IS $=1-3.5$ on clypeus. $\mathrm{CPL}: \mathrm{CAL}: \mathrm{APL}=0.31: 0.60: 0.16$, Genal area narrower than eye, $\mathrm{EW}: \mathrm{GW}=0.37: 0.34$, surface with small $\mathrm{PP}$, shiny and smooth near eye and shagreened behind. Mesosoma: Pronotum with lateral ridges acute but not extending below; lateral surface weakly shiny and shagreened. Mesoscutum smooth and shiny with PP, $8-10 \mu \varnothing$, IS $=0.5-1.5$, scutellum medially not depressed longitudinally, with smaller PP, $8-10 \mu \varnothing$, IS $=0.5-3.5$. Scutellum : metanotum : propodeal dorsum $=$ $0.31: 0.21: 0.28$. Propodeal side homogeneously tessellate with indistinct sparse PP, with lineolation below; propodeal dorsum with enclosure flat, ridges irregular, occupying basal $4 / 5$ rugosed, and apical 1/5 tessellate, lateral field smooth and shiny; propodeal declivity weakly tessellate with sparse PP. Tegula nearly smooth broadly. Inner hind tibial spur with 2 - 3 relatively long and round-tipped teeth. Metasoma: T1 smooth and shiny with small, sparse PP basally, $7-8 \mu$, IS $=1-3$, sparser PP on apical narrow area, T2, 3 very weakly tessellate and a little more roughened with sparser PP, $7-10 \mu \varnothing$, IS $=1-2.5$. Pygidial plate U-shaped. Metasomal sterna weakly tessellate with small indistinct PP.

Specimens examined: TURKMENISTAN: 1 female, Nebit-Dag, 1. v. 1993 (J. Halada).

Remarks: The female of this species is similar to Halictus varentzowi Morawitz. But it is recognized by the clypeus notably high, the supraclypeus slightly higher than clypeus, and the genal area, mesoscutum and metasomal terga covered with dense, felt-like yellowish hairs..

Distribution: China: Xinjiang; Turkmenistan. 
Floral association: Not available.

\section{Halictus (Seladonia) dorni Ebmer}

(Fig. 39: A-E, 40: A-B)

Halictus (Seladonia) dorni Ebmer, 1982, Mitt. zool. Mus. Berlin, 58: 204-205 [female, Mongolia]; Ebmer, 1988, Senckenbergiana biol., 68: 362.

\section{Redescription.}

Female. Body: $7.7 \mathrm{~mm}$, fore wing with tegula $5.6 \mathrm{~mm}(\mathrm{n}=1)$.

Color: Generally clear, more lively bacause of yellow-blue reflections, especially on face, mesoscutum; non-metallic parts rather blackish; flagellum beneath yellowish brown; scape and pedicel blackish; mandible dark brownish; tegula brownish yellow, transparent; veins and pterostigma yellow; tibial spurs yellow; legs brownish; posterior margins of metasomal terga yellowish brown, transparent.

Pilosity: Generally paler, non tomental hairs whitish and shorter, $100-150 \mu$ on vertex, $175-200 \mu$ on face, $125 \mu$ on mesoscutum centrally and $200-225 \mu$ on scutellum marginally, 200-250 $\mu$ on propodeum and sternal scopa $180-250 \mu$; tegula with anterior hairs short; tomental patch on gena with appressed, dense hairs and covering the surface well; tomental hairs behind lateral lobe of pronotum small but dense; basilateral patch on T1 small.

Structure: Head: HW : HL = $1.86: 1.93 ; \mathrm{HW}: \mathrm{MsW}: \mathrm{MtW}=1.86: 1.87: 2.20$. Vertex round in frontal view, roughened with distinct PP. Mean ratio of $\mathrm{IOD}: \mathrm{OOD}: \mathrm{OCD}=0.41$ : 0.33: 0.30. Eyes with inner margins subparalleled; MOD: UOD: $\mathrm{LOD}=1.33: 1.20: 1.27$. Postocellar PP 15 - 20 $\mu$, rather ill-defined; ocellocular PP $20-28 \mu \varnothing$, IS = $0.2-1.0$, postocellar depression relatively conspicuous. Frons distinctly convex; frontal carina relatively long, usually longer than carina-ocellus distance. Paraocullar area with epistomal angle roundly obtuse, lower margin slightly ascending laterad, PP 25 - $28 \mu$ ø above, 25 $30 \mu \varnothing$ below, IS $=0.1-1.0$. Supraclypeus notably higher than clypeus, with PP $15-30 \mu \varnothing$. Clypeus slightly convex, CPL : CAL : APL $=0.53: 0.87: 0.30$, smooth and shiny, with PP sparse, $\varnothing 15-25 \mu$, IS $=0.5-5$. Genal area broader than eye, EW : GW $=0.47: 0.66$, surface shagreened. Mesosoma: Pronotum without lateral ridge; lateral surface coriaceous and shagreened. PP on mesoscutum and scutellum homogeneous, 15 - 30 $\varnothing$, IS $=0.1-1.0$, scutellum medially not depressed longitudinally. Propodeal side homogeneously shagreened, with indistinct, sparse PP below. Scutellum : metanotum : propodeal dorsum = $0.4: 0.27: 0.36$. Propodeal dorsum with enclosure mildly depressed, ridges irregular, occupying basal 4/5 rugosed, apical 1/5 tessellate; apical area of dorsum mildly raised; lateral field rather broadly impunctate and shining; propodeal declivity smooth and shiny with sparse PP. Inner hind tibial spur with 4 - 5 relatively long and round-tipped teeth 


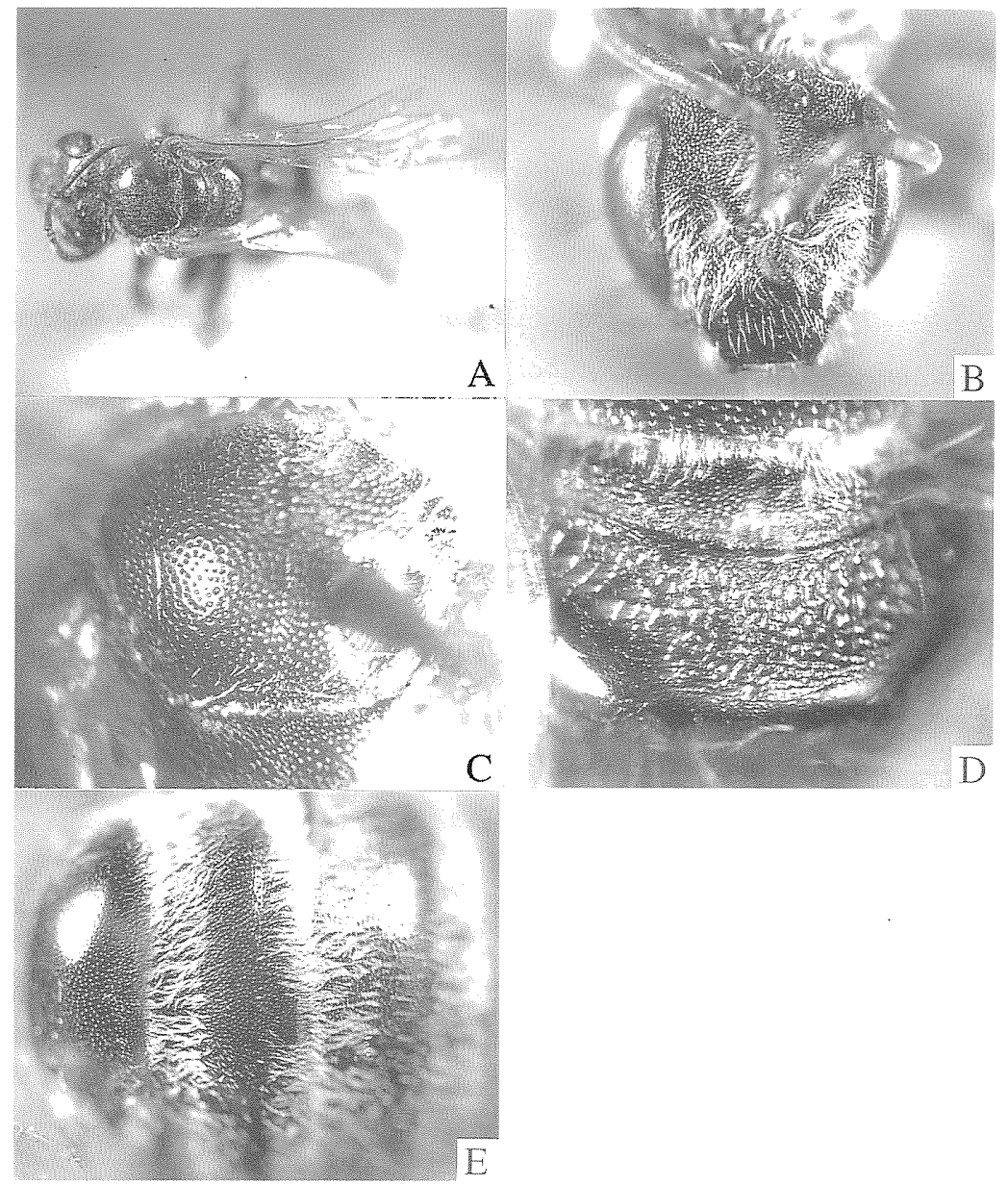

Fig. 39: A - E. Halictus (Seladonia) dorni Ebmer, female. A: general habitus; B: head in frontal view; C: mesoscutum; D: propodeum; E: metasomal terga.

issuing rather perpendicularly. Metasoma: T1 smooth and shiny with dense PP basally, more sparse PP, $12-15 \mu \varnothing$, IS = 0.2 - 1.5 medially; T2, 3 smooth and shiny with weaker and denser PP, $12-15 \mu \varnothing$, IS $=0.1-1.0$. Metasomal sterna weakly tessellate with indistinct PP.

Specimens examined. Paratype: MONGOLIA: 1 female, St. Ic. 1., 24. vii. 1979, MVRExped. Bajanchongor Aimag, Ich-bogd, 20km S, Bogd, S-Ufer Orognuur, Belfläche, 1350 $\mathrm{m}$ NN (Dorn).

Remarks: The female of this species is similar to Halictus leucaheneus Ebmer. But it is recognized by the clypeus strongly convex, the supraclypeus area higher than clypeus, and the metasomal tergum 1 with basilateral patch much smaller.

lower parts of clypeus, tibia, tarsus yellow, ventral surface of flagellum yellowish brown, antenna reaching propodeum, the basis of metasomal tergum 1 without hairs and the 

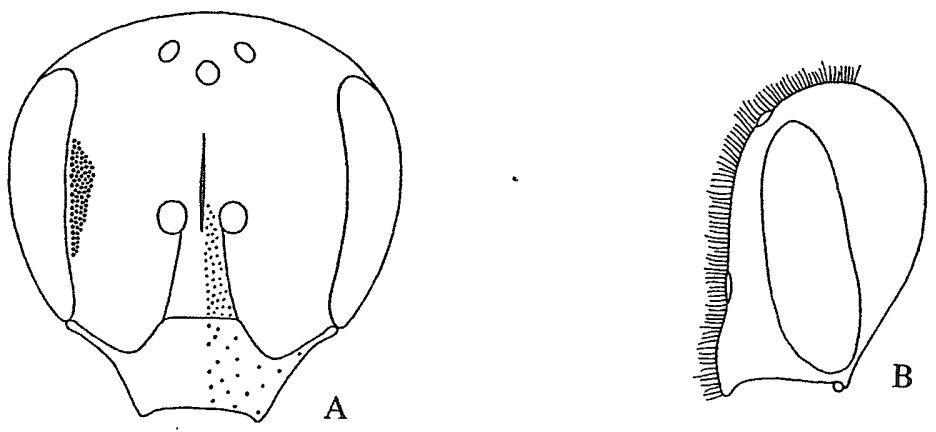

Fig. 40: $\mathbb{A}-\mathbf{B}$. Halictus (Seladonia) dorni Ebmer, A: frontal view of the head, female; B: lateral view of the head, female.

pubescence of metasomal terga scarcer.

Distribution : Mongolia.

Floral association : Ebmer (1982) recorded Halymondendron.

16. Halictus (Seladonia) tumulorum higashi Salkagami \& Ebmer

(Figs. 41: A-E , 42: A-E, 43: A-H)

Halictus (Seladonia) tumulorum higashi Sakagami \& Ebmer, 1979, Kontyû, 47 (4): $543-$ 549 [female \& male, Japan: Hokkaido]; Ebmer, 1982, Mitt. zool. Mus. Berlin, 58: 204; Fan, 1991, Acta ent. Sinica, 34 (4): 479 [in key, China]; Ebmer, 1996, Linzer biol. Beitr., 28: 269.

Halictus daturae Gussakovskij, 1933 (nec Cockerell, 1929): 24.

Halictus (Seladonia) tumulorum: Sakagami \& Fukushima, 1961: Jap. J. Ecol., 118;

Sakagami \& Fukuda, 1972, Res. Bull. Coll. Exp. Forest, Coll. Agric., Hokkaido Univ., 29: 4; Fukuda et al., 1973, Jap. J. Ecol., 23: 163; Sakagami \& Fukuda, 1973: J. Fac. Sci., Hokkaido Univ., Zool., 19: 221; Sakagami et al., 1974, Mater. Biol. Educ., 9: 32; Ebmer, 1978, Bonn. zool. Beitr., 29: 189; Ebmer, 1978, Ann. Hist-nat. Mus. Nat. Hung.: 309.

Halictus tumulorum: Hirashima, 1965, Iconogr. Insect Jap. Col. nat. ed., 3: 305; Hirashima, 1966, Kontyû, 34: 3.

Halictus (Seladonia) ref. tumulorum: Usui et al., 1976, Bull. Obihiro Univ., 10: 228; Munakata et al., 1978, Mater. Biol. Educ., 13: 40. 


\section{Redescription.}

Female. Body: 7.60 - $8.70 \mathrm{~mm}$, fore wing with tegula 5.00 - $6.10 \mathrm{~mm}(\mathrm{n}=10)$.

Color: Generally dark, weakly golden green reflections; non-metallic parts rather brownish than blackish; mandible blackish brown; flagellum beneath brownish, scape and pedicel blackish; lateral lobe of pronotum blakcish; tegula brownish transparent; veins and pterostigma yellowish brown; legs blackish brown, tibial spurs yellow; posterior margins of metasomal terga yellowish transparent.

Pilocity: Generally yellowish white to pale fulvous, $250-300 \mu$ on vertex, $280-360 \mu$ on face, $260-280 \mu$ on pronotum, $220-250 \mu$ on mesoscutum centrally, $230-280 \mu$ on scutellum marginally and sternal hairs posteriorly $260-330 \mu$; tomental hairs behind lateral lobe of pronotum plenty; tegula with yellowish short hairs anteriorly; $\mathrm{T} 1$ without basilateral patch; apical hair bands of terga wide and developed, T1 interrupted, T2 medially narrow but only rarely interrupted, T3-4 complete, surface with short yellowish hairs.

Structure: Head: HW : HL $=1.93: 1.87$; HW $: \mathrm{MsW}: \mathrm{MtW}=1.93: 1.90: 2.20$. Vertex flat in frontal view shiny and smooth with a little roughened PP. Mean ratio of IOD : OOD $: \mathrm{OCD}=0.33: 0.39: 0.21$. Eyes with inner marigins subparallelled, MOD $: \mathrm{UOD}: \mathrm{LOD}=$ $1.33: 1.30: 1.03$. Postocellar PP, $25 \mu \varnothing$, rather ill-defined, ocellocular PP, $25-28 \mu \varnothing$, IS = 0.1 - 1, postocellar depression relatively conspicuous. Frons nearly flat; frontal carina relatively short, shorter than carina-ocellus distance. Paraocular area with epistomal angle roundly obtuse, lower margin slightly ascending laterad, PP, $25-28 \mu \varnothing$, IS $=0.1-1$ above, $25-30 \mu \varnothing$, IS $=0.2-1$ below. Supraclypeus slightly higher than clypeus, with PP, 20 $30 \mu \varnothing$, IS $=0.2-1.5$. Clypeus nearly flat, $\mathrm{CPL}: \mathrm{CAL}: \mathrm{APL}=0.40: 0.85: 0.25$, smooth and shiny with sparse PP, $20-35 \mu \varnothing$, IS $=0.1-2$. Genal area broader than eye, EW : GW = $0.40: 0.47$, surface with small PP and IS shagreened. Mesosoma: Pronotum without lateral ridges; lateral surface weakly shiny and shagreened. Mesoscutum smooth and shiny with distinct PP, $25-30 \mu \varnothing$, IS $=0.1-1$, scutellum medially not depressed longitudinally, with denser and smaller PP anteromedially. Scutellum : metanotum : propodeal dorsum $=0.40$ : $0.23: 0.39$. Propodeal side homogeneously weakly tessellate with indistinct sparse PP; propodeal dorsum with enclosure slightly depressed, ridges occupying basal 4/5 rugosed, and apical $1 / 5$ shagreened, medial portion with fairly irregular and partly parallelled ridges; lateral field weakly tessellate and weakly shiny, broadly impunctate except above; propodeal declivity weakly tessellate with sparse PP. Tegula nearly smooth broadly. Inner hind tibial spur with 5 - 6 relatively long and round-tipped teeth. Metasoma: T1 smooth and shiny with small, dense PP basally, $8-18 \mu \varnothing$, IS $=0.1-2$, sparser PP on apical narrow area, T2, 3 weakly tessellate and a little more roughened with sparser PP, $8-25 \mu \varnothing$, IS = 0.5 - 1.5. Pygidial plate U-shaped. Metasomal sterna weakly tessellate with small indistinct PP. 


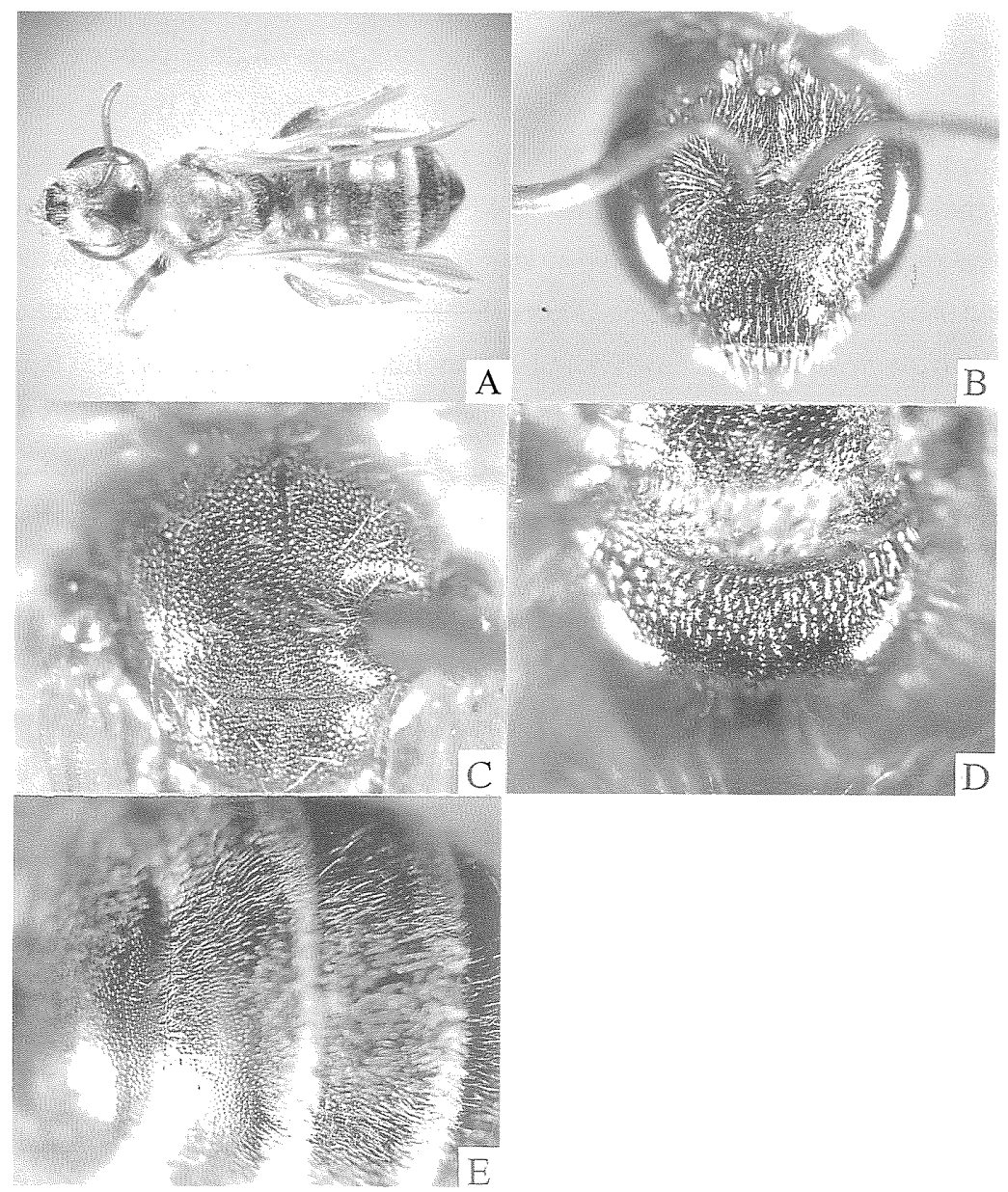

Fig. 41: $\mathbb{A}$ - E. Halictus (Seladonia) tumulorum higashi Sakagami \& Ebmer, female. A: general habitus; B: head in frontal view; C: mesoscutum; D: propodeum; E: metasomal terga.

Male. Body: $7.55-8.65 \mathrm{~mm}$, fore wing with tegula $5.3-6.60 \mathrm{~mm}(\mathrm{n}=10)$.

Color: As in female, non-metallic parts rather blackish; metasomal terga marginally brownish, transparent; apical half of clypeus, labrum, central part of mandible yellow; tegula brownish yellow transparent; femur yellowish mostly brownish partly; tibia and tarsi yellow.

Pilosity: Hairs yellowish, $200-235 \mu$ on vertex, $200-270 \mu$ on face, $190-230 \mu$ on pronotum, $230-260 \mu$ on mesoscutum centrally, $270-330 \mu$ on scutellum marginally and sternal hairs posteriorly $150-170 \mu$; genal tomental patch developed; metasomal terga with sparse yellowish white hairs apically.

Structure: Head: HW : HL = $1.93: 2.16$; HW $: \mathrm{MsW}: \mathrm{MtW}=1.93: 2.00: 1.83$. Vertex round in frontal view. Postocellar with distinct PP, $25-28 \mu \varnothing$, IS $=0.2-1$, shagreened. Ocellocular area with similar PP, 25 - 30 $\mu$, IS $=0.2$ - 1.2. Flagellar segments F1-3 L, F10 
$\mathrm{L}$ and F2 $\mathrm{W}=0.28: 0.35: 0.36: 0.39: 0.21$. Supraclypeus slightly convex, with rather denser and stronger PP, $20-30 \mu \varnothing$, medially, IS $=0.1-1$, rarely 2 . Clypeus with PP, 10 $30 \mu \varnothing$, IS $=0.2-3 ;$ CPL : CAL : APL $=0.50: 0.97: 0.28$, not much coarser and sparser below. Genal area broader than eye, EW : GW $=0.40: 0.59$. Mesosoma: Pronotum with many lateral ridges but not extending blow, lateral surface smooth and shining. Mesoscutum smooth and shiny with distinct PP, $25-30 \mu \varnothing$, IS $=0.2-1$, scutellum medially not depressed longitudinally, with similar PP. Scutellum : metanotum : propodeal dorsum $=0.39: 0.27$ : 0.38 . Propodeal side with relatively dense and distinct PP of $20-30 \mu \varnothing$, IS $=0.2-2$, nearly smooth and shiny. Propodeal dorsum with enclosure mildly depressed, with stronger irregular ridges medially, lateral part with rather sparse PP; propodeal declivity with PP. Tegula smooth and shiny with fine PP. Hind tibia : hind basitarsus : hind distitarsus $=1.40$ : $0.90: 1.07$. Metasoma: T1 nearly smooth and shining all over; anterior declivity with

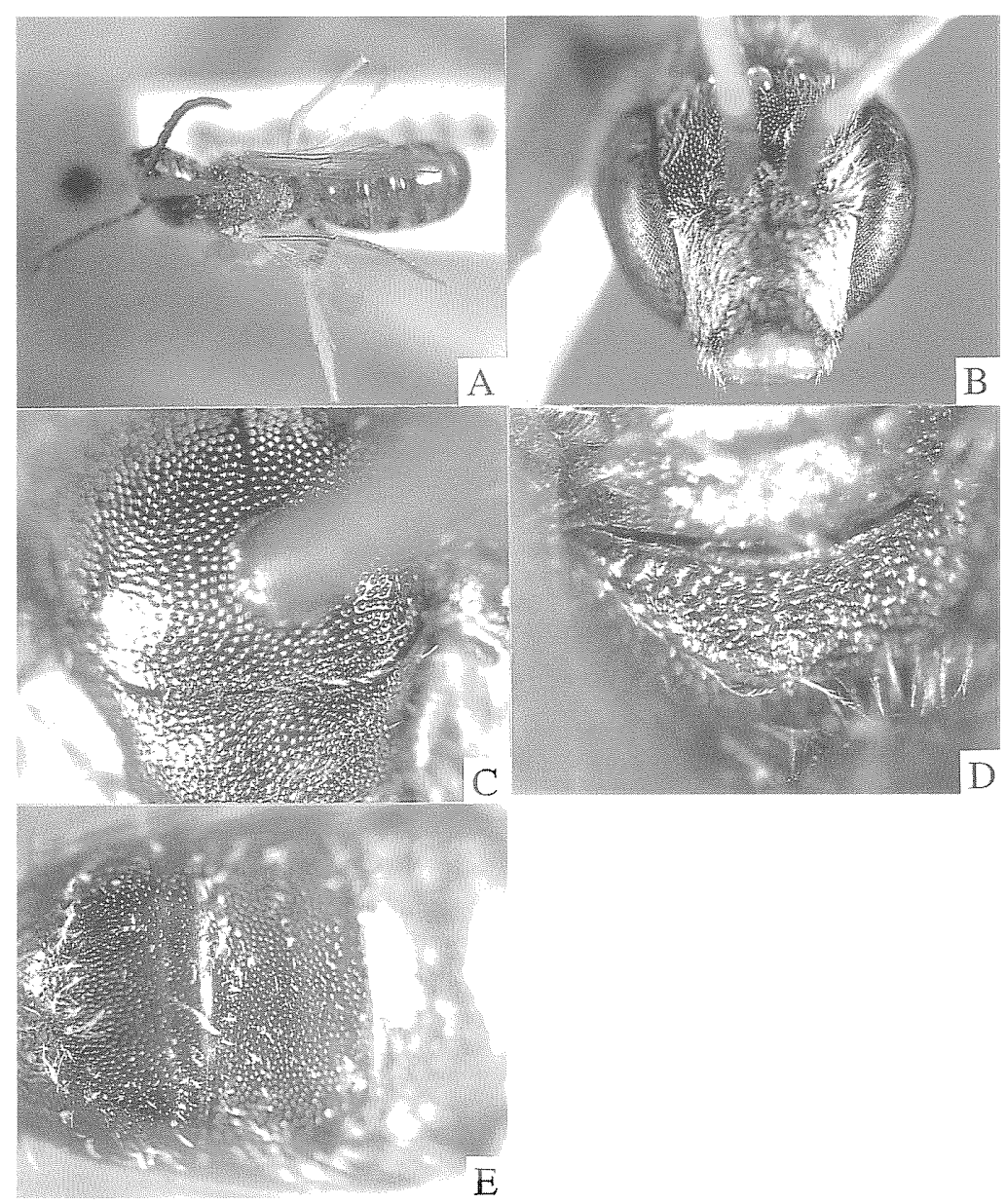

Fig. 42: A - E. Halictus (Seladonia) tumulorum higashi Sakagami \& Ebmer, male. A: general habitus; B: head in frontal view; C: mesoscutum; D: propodeum; E: metasomal terga. 

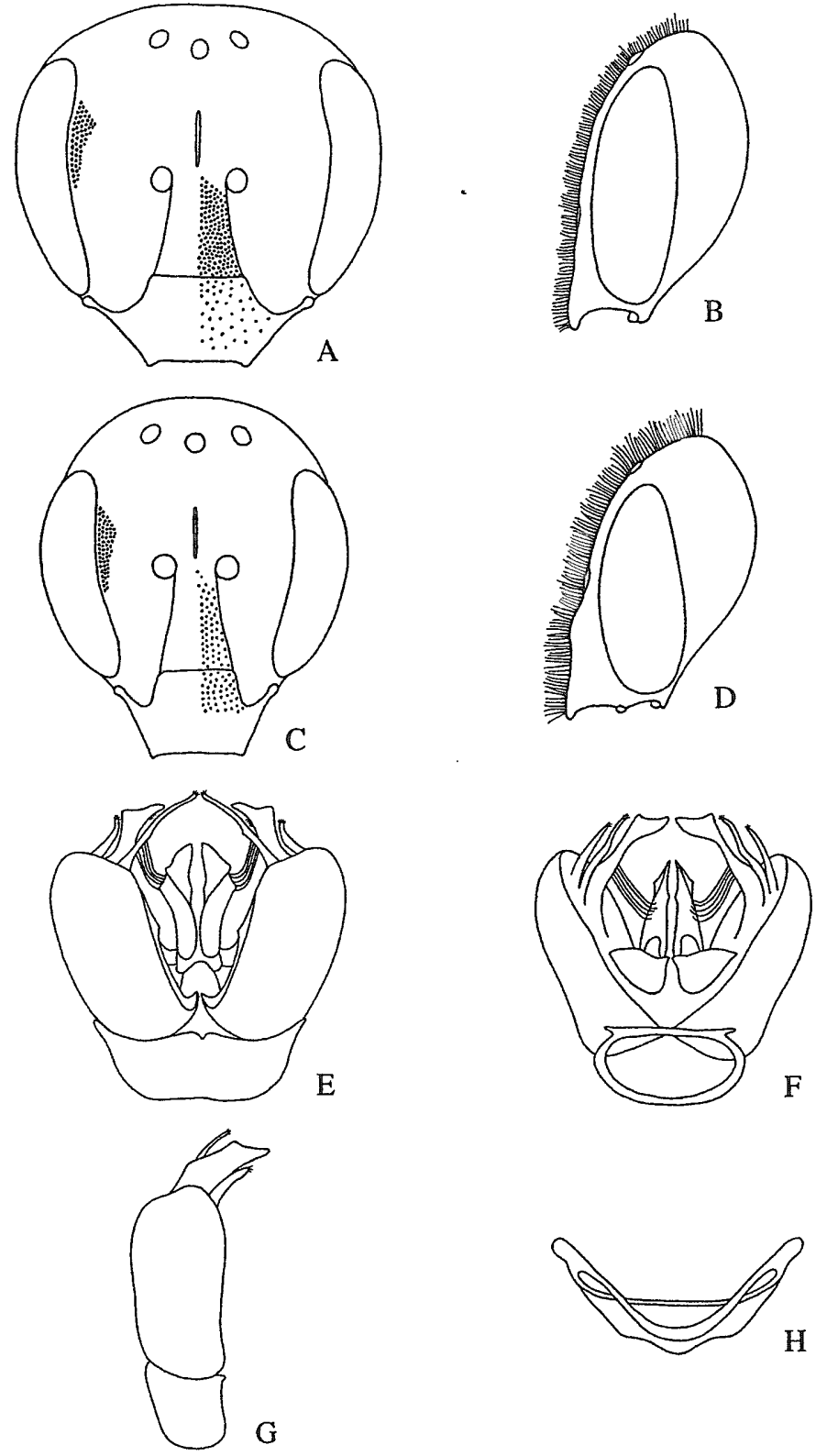

Fig. 43: A - H. Halictus (Seladonia) tumulorum higashi Sakagami \& Ebmer, A: frontal view of the head, female; B: lateral view of the head, female; $\mathrm{C}$ : frontal view of the head, male; D: lateral view of the head, male; $\mathrm{E}$ : dorsal view of the male genitalia; $F$ : ventral view of the male genitalia; G: right lateral view of the genitalia; H: sterna 7 and 8 of the male. 
rather sparse PP, disc with dense $8-18 \mu \varnothing$, IS $=0.1-2$, marginal area with very sparse PP; T2-4 similar to T1 with PP rather roughened. T7 not elongated, smooth and shiny with round apex without carination. S8 medially mildly rounded, apex not pointed. Genitalia: Gonostylus subbasally fairly acutely convex, apex not dilated outwardly, tufted hairs very short; modified hairs long; dorsal lobe long and medial part weakly dilated outwardly; ventral lobe shorter than main body, with sparse hairs only apically.

Specimens examined: JAPAN: Hokkaido: Paratypes: Hokkaido University Campus, Sapporo (Sakagami): 2 females, 11. vi. 1959; 1 female, 26. vi. 1959; 1 female, 6. vii. 1959; 1 male, 28. vii. 1959; 1 male, 14. viii. 1959; 1 male, 17. viii. 1959; 1 male, 3. ix. 1959; 2 males, 7. ix. 1959; 2 males, 8. ix. 1959; 1 female, 14. ix. 1959; 1 male, 16. ix. 1959; 1 male, 25. ix. 1959. Other than paratypes: 2 males, Hamakoshimizu, 28. ix. 1966; 1 female, Inosawa, Asahikawa, 10, vi. 1969; 2 females, Asahiyama, Asahikawa, 11. vi. 1969; 3 females, Asahiyama, Asahikawa, 25. vi. 1969; 6 females, Inosawa, Asahikawa, 27. vi. 1969; 1 female, Asahiyama, Asahikawa, 15. vii. 1969; 1 female, Inosawa, Asahikawa, 26. viii. 1969; 1 female, Asahiyama, Asahikawa, 24. ix. 1969; 3 females, Inosawa, Asahikawa, 29. v. 1970; 6 females, Asahiyama, Asahikawa, 30. v. 1970; 1 female, Inosawa, Asahikawa, 10. vi. 1970; 1 female, Inosawa, Asahikawa, 25. vii. 1970; 1 female, Inosawa, Asahikawa, 11. viii. 1970; 5 females, Kiritappu Highmoor, 1972 (Y. Uehira); 1 female, Asahiyama, Asahikawa, 24. v. 1985 (T. Inaoka); 4 females, Asahiyama, Asahikawa, 17. ix. 1985 (T. Inaoka); 5 females, Rebun Is., 24. vi. 1979 (K. Hoshikawa).

Remarks: The eastern subspecies H. tumulorum higashi is separated from the European nominate subspecies by the apical hair bands of female metasomal terga more developed and the punctures on the head, mesoscutum behind and scutellum larger, shallower and sparser.

Distribution: Japan (Hokkaido, northern Honshu); North Korea; China (northeast); Mongolia; Russia (Far East area).

Floral association: Allium fistulosum L, Anthriscus nemorosa L., Brassica campestris L., Dasyphora fruticosa Rydberg Erigeon annuus L., Geranium erianthum DC, Geranium Thunbergii Sieb. et Zucc., Heracleum dulee Pischer, Laburnum anaayroides Medic., Lathyrus japonicus Willdenow, Ranunculus sp., Rokyanthus perulatus Schneider_Rorippa atrovirens O. et H., Rosa polyantha Sieb.et Zucc., Rudbeckia laciniata L., Solidago canadensis L., Sonchus brachyotus Fischer et DC, Spiraea grandifolia Tatewaki, Taraxacum officinale L., Dendelion sp., Trifolium repens L., Lithospermum erythrorhizon Sieb. et Zucc., Barbarea vulgaris var. stricta Regel. 